\title{
Gümüşhane İli Meralarına Ait Vejetasyon ve Bazı Çevresel Özelliklerin Jeoistatistiksel Analizi
}

\author{
Geostatistical Analysis of Gümüşhane Grasslands According to Vegetation and Some \\ Environmental Features
}

\author{
Mustafa SÜRMEN ${ }^{1, a}$, Tamer YAVUZ ${ }^{2, b}$, Burak SÜRMEN*3,c , Ali İMAMOĞLU ${ }^{4, d}$ \\ ${ }^{1}$ Adnan Menderes Üniversitesi, Ziraat Fakültesi, Tarla Bitkileri Bölümü, 09010, Aydın \\ ${ }^{2}$ Ahi Evran Üniversitesi, Ziraat Fakültesi, Tarla Bitkileri Bölümü, 40200, Kırşehir \\ ${ }^{3}$ Karamanoğlu Mehmetbey Üniversitesi, Kamil Özdağ Fen Fakültesi, Biyoloji Bölümü, 70100, Karaman \\ ${ }^{4}$ Nevşehir Hacı Bektaş Veli Üniversitesi, Fen-Edebiyat Fakültesi, Coğrafya Bölümü, 50300, Nevşehir
}

• Geliş tarihi / Received: 24.10.2019 • • Düzeltilerek geliş tarihi / Received in revised form: 17.01.2020 • Kabul tarihi / Accepted: 30.01 .2020

\begin{abstract}
$\ddot{O} z$
Meralar yeryüzünün genelinde olduğu gibi Türkiye'de de küçük ve büyükbaș hayvanların beslenmesinde kullanılan en önemli yem kaynaklarındandır. Son yıllarda iklim değişikliği gibi küresel ölçekte meydana gelen faktörlerin yanı sıra, aşırı otlatma ve arazi kullanımında yapılan hatalar meraların kalitesini olumsuz etkilemektedir. Bu çalışma ile Gümüşhane ili meralarının vejetasyon özellikleri ile bazı çevresel faktörlere göre değerlendirilmesinin yanında jeoistatistik yöntemlerle çizilen haritalar ile Gümüşhane ilindeki tüm mera ve yaylaların durumunun ortaya konulması amaçlanmıştır. Bu yayla ve meraların eğim, toprak derinliği, erozyon derecesi, otlatma baskısı ve taşlık çevresel faktörleri ile azalıcı, çoğalıcı, istilacı bitkilerin kompozisyon oranları, baklagiller ve buğdaygiller familyasına ait bitkilerin kompozisyon oranları ve mera sağlık sınıfı ile mera durum sınıfına ait özelliklerin dağılım haritaları çizilmiştir. Elde edilen sonuçlara göre meraların $\% 65$ 'inde orta ve yüksek dereceli erozyon görülürken, meraların büyük çoğunluğu çok sığ ve sığ derinlikte topraklara sahiptir. 12 merada aşırı otlatma tespit edilmiştir. Son olarak mera kalitelerine baktığımızda; 10 meranın kalitesinin kötü olduğu diğerlerinin ise orta ve daha iyi sevilerde olduğu tespit edilmiştir.
\end{abstract}

Anahtar kelimeler: Enterpolasyon, Jeoistatistik, Mera

\begin{abstract}
Rangelands are the most important sources used in animal feedings in Turkey as Earth. In recent years, global factors such as climate change, overgrazing and land use mistakes adversely affect the quality of rangelands. This study aims to evaluate the quality of the rangelands and uplands in the Gümüshane according to vegetation features and some environmental factors and additionally the maps drawn by geo-statistical methods will reveal the status of all rangelands Gümüşhane. The slope, soil depth, degree of erosion, grazing pressure and stony from environmental factors and composition ratios of decreaser, increaser, invader plants, composition ratios of legume, grasses and other families and distribution maps of range health classifications and range condition classification were draw. According to the results, moderate and high erosion is observed in $65 \%$ of the rangelands, while the majority of the rangelands have very shallow and shallow depth soils. Overgrazing was detected in 12 pastures. Finally, when we look at the rangelands quality; the quality of 10 site was found to be poor and the others were found to be moderate and better.
\end{abstract}

Keywords: Interpolation, Geostatistic, Rangeland

\footnotetext{
*c Burak SÜRMEN; buraksurmen@gmail.com, Tel: (0554) 72506 61, orcid.org/0000-0002-4055-613X

${ }^{\mathrm{a}}$ orcid.org/0000-0001-9748618X $\quad{ }^{\mathrm{b}}$ orcid.org/0000-0002-7374-7899 $\quad{ }^{\mathrm{d}}$ orcid.org/0000-0001-9197-1029
} 


\section{Giriş}

Yeryüzündeki meralar hayvanc1lık için önemli besin alanlarını oluştururlar. Türkiye'de özellikle Karadeniz bölgesindeki meralar besin kalitesi yönünden en verimli alanlar olarak kabul edilmektedir (Ayan vd., 2007). Kaba yem ihtiyacının önemli bir kısmının sağlandığı meralar özellikle Anadolu'da küçükbaş hayvancıllı̆̆ın şekillenmesinde önemlidir. Ülkemizde uzun y1llardır meralar kullanılmasına rağmen, bu alanlar için sslah ve amenajman gibi teknik uygulamalar, bitkilerinin büyüme ve gelişmesi için gereksinimlerinin neler olduğu ve hayvan otlatmanın düzenlenmesi gibi uygulamaların yapılmaması nedeni ile bu alanların aşırı şekilde kullanılmasına yol açmıştır (Cevher vd., 2015). $\mathrm{Bu}$ sebeple mera arazileri yıllar içerisinde çeşitli sebeplerle kullanılamaz ya da verimi düşük araziler haline gelmiştir. Günümüzde meralarda yem değeri yüksek bitkilerin yoğunluklarının azalması, istilacı ve yem değeri düşük olan diğer familyalara ait bitkilerin artmas1 botanik kompozisyonda değişmelere neden olmaktadır (Büyükburç, 1983).

Doğal alanlar olarak kabul edilen mera ekosistemleri, birçok çevresel faktörün etkisi altındadır. Özellikle; iklim, topoğrafya, toprak ve canlı organizmalar başlıca faktörlerdir (Şengönül vd., 2009). Son y1llarda özellikle biyosferde meydana gelen farklılıkların yeryüzünde etkilediği birçok ekosistem gibi meraları da olumsuz etkilemektedir (Sürmen vd., 2015). Bunun sonucu olarak mera vejetasyonlarının sahip olduğu bitki çeşitliliğinin giderek azalmasına neden olmaktadır (Karagüllü ve Kendüzler, 2008). Meraların maruz kaldığ1 bir diğer olumsuz faktör ise aşırı otlatmadır. Özellikle Karadeniz bölgesi meraları ilkbahar, yaz ve sonbaharın belirli dönemlerinde yoğun otlatma ile karşı karşıya kalmaktadır (Sürmen vd., 2015). Bu durum otlatmaya karş1 dirençli olan ve yem değeri olmayan bitki türlerinin çoğalmasına neden olmaktadır (Sürmen ve Kara, 2018).

İklim faktörleri, toprak ve topoğrafya özellikleri meraların vejetasyonlarının oluşumunda ve klimaksa ulaşmasında en önemli etkenlerdir. Meraların klimaksa ulaşması uzunca bir süreç olup, eğer çevresel faktörlerin değişmesi veya çeşitli faktörler (otlatma, yapılaşma vb.) ile baskılanmas1 durumunda meraların vejetasyon yapısı olumsuz yönde etkilenecektir (Blanchet vd., 2003). Sonuç olarak; meralarda vejetasyon sabit olmayıp sürekli değişkenlik gösteren dinamik bir yapıya sahiptir. Ülkemiz meralarında önceki yıllarda yapılan mera etüdü çalışmalarında, meraların botanik kompozisyonlarındaki klimaks bitki türlerinin büyük çoğunluğunun sayı ve oran olarak oldukça azaldığ kaybolduğu ifade edilmektedir (Yavuz vd., 2012; Ünal vd., 2014; Turan vd., 2015).

Günümüzde bir yöreye veya bir bölgeye ait özelliklerin mekânsal dağılımları farklı jeoistatistik metotlarla belirlenmektedir (İmamoğlu ve Dengiz, 2019). Bu metotların kullanılarak çizilen haritalar ile zaman içinde meydana gelebilecek değişimler izlenebilmektedir. 1951 y1lında kullanılmaya başlanan bu yöntemler günümüzde yaygın hale gelmiştir. Özellikle son y1llarda vejetasyon ve çevresel özelliklere ait verilerin mekânsal dağılımlarını belirlemek için çizilen haritalar ile bu alanların çeşitli parametrelere ait verimlilik, risk, değişim, baskınlık vb. haritaları çizilerek bölge için yapılacak planlamalar için faydalı veri tabanları oluşturulmaktadır (McGrath vd., 2004; Ongun, 2008; Aksakal ve Öztas, 2010; Turgut ve Öztas, 2012).

$\mathrm{Bu}$ çalışmada, meraların botanik kompozisyonlarına ve çevresel özelliklerine ait veriler jeoistatiksel yöntemler ile analiz edilerek ele alınan meraların haritaları çizilerek ileride yapılması planlan çalışmalar için gerekli veri tabanları oluşturulması amaçlanmıştır.

\section{Materyal ve Metot}

\subsection{Araştırma Sahasının Yeri ve Sınırları}

Araştırma sahası kuzeyinde Trabzon, batısında Giresun, doğusunda Bayburt ve güneyinde Erzincan illerinin komşusu olan Gümüşhane ili sınırları içerisinde yer alan mera arazilerinde gerçekleştirilmiştir (Şekil 1). Gümüşhane ili, 6.575 kilometrekare yüz ölçüme sahiptir. İlin güney kesimleri Harşit çayı tarafindan derince yarılmıştır. İl merkezi de bu vadi üzerinde kurulmuştur. Kuzeyde ise akarsular tarafindan derince yarılmış yüksek sahalar bulunmaktadır. Zigana dağları, Gümüşhane dağları ve Çimen dağları ilin doğu batı doğrultusunda uzanan yüksek dağlık kütleleridir. Gümüşhane ilinin yıllık toplam yağış değeri $816 \mathrm{~mm}$ 'dir. En çok yağış Nisan $(60.7 \mathrm{~mm})$ ve Mayıs $(65.8 \mathrm{~mm})$ aylarında meydana gelmektedir. İlin y1llık ortalama sicaklık değerleri $7.9^{\circ} \mathrm{C}$ dir. Ortalama sicaklıklar Ocak ve Şubat aylarında $0^{\circ} \mathrm{C}$ 'nin altına düşmektedir. En sicak aylar $20.1^{\circ} \mathrm{C}$ ile Temmuz ve Ağustos aylarıdır. 
Meraların vejetasyon ölçümleri modifiye edilmiş tekerlekli lup (halka) metodu kullanılarak, meralardaki hâkim bitkilerin çiçeklenme evresinde (Koç ve Çakal, 2004) gerçekleştirilmiştir. Bitki teşhisinde Davis (1965, 1985), Davis vd. (1988), Güner vd. (2000) kaynaklarından faydalanılmıştır. Okuma neticesinde tespit edilen bitki türleri azalıcılar, çoğalıcılar ve istilacılar olmak üzere 3 sınıfa ayrılmışlardır. Tespit edilen bitkilerden azalıcıların tamamı ve çoğalıcıların ise \%20'si dikkate alınarak çalışılan meralarda mera durumu ve mera sağlık sınıflaması yapılmıştır (Koç vd., 2003). Bitki örtüsünün toprağı kaplama oran1, vejetasyon etüdü sırasında bitkiye rastlanan nokta sayısının ölçülen toplam nokta sayısına oranlanması ile belirlenmiştir (Gökkuş vd., 2000). Okunan her bir bitki türüne ait değerler, toplam bitki sayısına oranlanarak türlerin botanik kompozisyondaki oranlanı tespit edilmiştir.

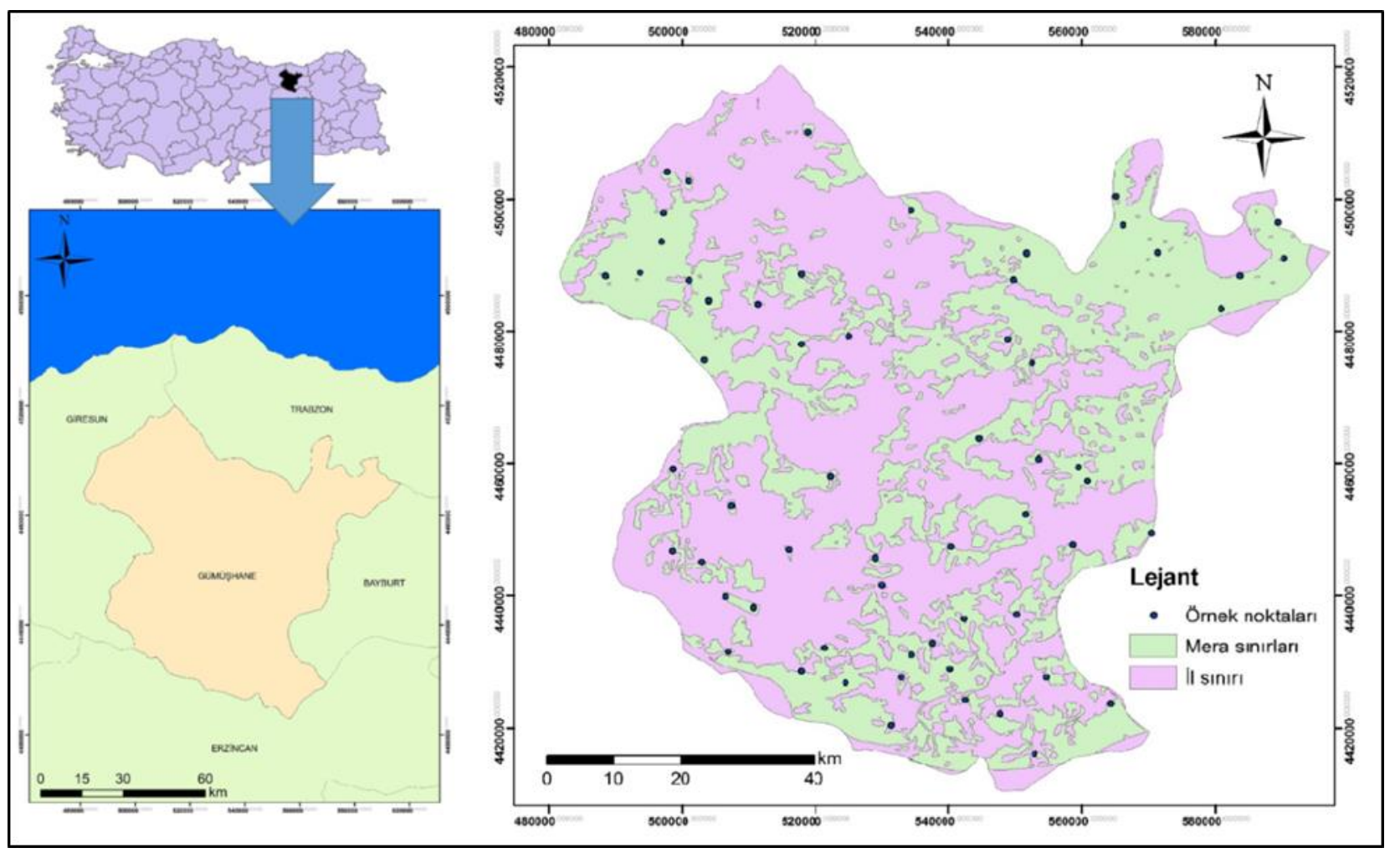

Şekil 1. Gümüşhane ili coğrafi konumu ve örnekleme alanları

Meraların çevresel özelliklerine ait olan erozyon derecesi, taşlilık, toprak derinliği ve otlatma şiddetine ait değerler arazi çalışmalarından elde edilmiştir. Meraların taşla kaplılık oranları modifiye edilmiş tekerlekli lup (halka) metodu kullanılarak hesaplanmıştır. İl arazi raporuna göre örnekleme alanlarının eğim dereceleri belirlenirken, erozyon dereceleri arazi gözlemleri ve il envanter bilgilerine dayanarak tespit edilmiştir. Meraların toprak derinliği ise arazi çalışmalarından ve alınan toprak örneklerinin büyük toprak grupları belirlenerek tespit edilmiştir. Son olarak otlatma şiddeti, arazi çalışmalarında gözlemlenen mera toprağındaki sıkışma durumu ve mera vejetasyonlarında bulunan bitki türlerine göre değerlendirilmiştir. Elden edilen sonuçlar mera amenajman ve sslah çalışmalarında kullanılan standart yöntemlere göre sinıflandırılmıştır. Meradaki etüt çalışmaları esnasında alınan gözlemler Tablo 1'deki skalaya göre kaydedilmiştir (Anonim, 2005).

Tablo 1. Çevresel özelliklerin sınıflandırma değerleri

\begin{tabular}{lllll}
\hline Sınıflandırma değeri & Erozyon derecesi (ton/ha) & Taşlılık (\%) & Derinlik $(\mathbf{c m})$ & Otlatma \\
\hline 1 & Çok hafif $<2$ & Çok az $<1$ & Çok sı̆ $<19$ & Yok \\
\hline 2 & $2<$ Hafif $<4$ & $2<\mathrm{Az}<4$ & $20<$ Siğ $<49$ & Hafif \\
\hline 3 & $2<$ Orta $<4$ & $5<$ Orta $<14$ & $50<$ Orta derin $<89$ & Orta \\
\hline 4 & $2<$ Yüksek $<4$ & $15<$ Çok $<39$ & $90<$ Derin $<149$ & Yoğun \\
\hline 5 & $2<$ Şiddetli $<4$ & $40<$ Aşırı $<79$ & $150<$ Çok derin & Çok yoğun \\
\hline 6 & $2<$ Çok şiddetli $<4$ & $80<$ Baskın & & \\
\hline
\end{tabular}




\subsection{Jeoistatistiksel Analizler}

$\mathrm{Bu}$ çalışmada; vejetasyon özelliklerine (azalıcı, çoğalıcı, istilacı, baklagil, buğdaygil ve mera durum sınıfi) ve çevresel özelliklere (erozyon derecesi, taşl1lık, toprak derinliği ve otlatma şiddeti) ait alansal dağılım haritaları çizilmiştir. Ayrıca il arazi raporu kullanılarak arazi kullanım haritası çizilmiştir. Harita çizimleri vejetasyon ve çevresel parametrelere ait semivariyogram değerlerinin hesaplaması sonrası, en çok kullanılan IDW, RBF ve Kriging yöntemlerinden doğal (ordinary), evrensel (universal), basit (simple) kriging enterpolasyon hesaplamaları kullanılmıştır. Yöntemlere ait enterpolasyon hesaplamalarının karşılaştırılmalarında ölçülen değerler ve tahmin edilen değerler arasındaki ilişkiyi sorgulayabilmek, ölçülen değerlere en yakın sonucu veren başka bir ifade ile yöntemler arasından en uygun olanının seçebilmek için literatürde farklı karşılaştırma yöntemlerinin dikkate alındığı görülmektedir (İmamoğlu ve Dengiz, 2017). Analizler için kullanılan indekslerin hesaplanması ve alan içerisinde bu indekslerin dağılımlarının belirlenmesi amacıyla
ArcGIS $10.2 \mathrm{v}$ jeoistatistiksel modellerinden yararlanılmıştır (İmamoğlu vd., 2016). Bu çalışmada birden çok yöntem kullanılarak harita çizimi için en uygun olanı hata kareler ortalamasının karekökü (RMSE) değerlerine göre belirlenmiştir. Çünkü en düşük RMSE değerini veren yöntem en uygun yöntemdir (Arslan, 2012). $\mathrm{Bu}$ çalışma için vejetasyon ve çevresel özelliklere ait RMSE değerleri incelenmiş ve en düşük RMSE değerlerine sahip yöntemler haritaların çizimi için seçilmiştir (Tablo 2, Tablo 3).

$R M S E=\sqrt{\frac{\sum\left(z_{i *}-z_{i}\right)^{2}}{n}}$

Eşitlikte; $Z_{i}$ : tahmin edilen değer, $Z_{i^{*}}$ ölçülen değer ve $n$ örnek sayısını ifade etmektedir (Arslan, 2012).

Eğim ve arazi kullanımına ait bilgiler il envanter inde yer alan arazi raporlarından elde edilmiştir. $\mathrm{Bu}$ iki özelliğe ait haritaların çizimi için herhangi bir jeoistatistik hesaplamaya ihtiyaç olmadığı için RMSE değerleri de hesaplanmamıştır.

Tablo 2. Vejetasyon parametrelerine uygulanan jeoistatistiksel yöntemler

\begin{tabular}{|c|c|c|c|c|c|c|c|}
\hline \multirow{2}{*}{$\begin{array}{l}\text { Enterpolasyon } \\
\text { Models }\end{array}$} & \multirow{2}{*}{ Power Semivariogram } & \multicolumn{5}{|c|}{ RMSE } & \multirow[b]{2}{*}{ MSD } \\
\hline & & Azalıc1 & Çoğalıcı & İstilac1 & Baklagil & Buğdaygil & \\
\hline \multirow{3}{*}{ İDW } & 1 & 11.03 & 10.62 & 14.87 & 13.37 & 12.59 & 0.87 \\
\hline & 2 & 11.55 & 11.13 & 15.89 & 13.66 & 12.34 & 0.90 \\
\hline & 3 & 12.36 & 11.68 & 17.06 & 14.23 & 12.65 & 0.95 \\
\hline \multirow{5}{*}{$\mathrm{RBF}$} & $\begin{array}{l}\text { Completely } \\
\text { Regularized Spline }\end{array}$ & 11.09 & 11.01 & 15.32 & 13.17 & 12.22 & 0.89 \\
\hline & Spline With Tension & 11.03 & 10.90 & 15.15 & 13.15 & 12.22 & 0.88 \\
\hline & Multiquadric & 11.9 & 12.00 & 17.10 & 14.05 & 12.55 & 0.96 \\
\hline & İnverse Multiquadric & $10.97 *$ & 10.34 & 14.40 & 13.12 & 12.32 & 0.86 \\
\hline & Thin Plate Spline & 13.68 & 13.05 & 19.79 & 15.70 & 14.15 & 1.12 \\
\hline \multirow{3}{*}{$\begin{array}{l}\text { Ordinary } \\
\text { Kriging }\end{array}$} & Spherical & 11.04 & 10.32 & 14.50 & 13.13 & 12.20 & 0.87 \\
\hline & Exponential & 11.00 & 10.36 & 14.57 & 13.19 & 12.46 & 0.85 \\
\hline & Gaussian & 10.99 & 10.28* & 14.45 & $13.10 *$ & 12.40 & 0.85 \\
\hline \multirow{3}{*}{ Simple Kriging } & Spherical & 10.41 & 10.31 & 14.25 & 13.11 & 12.42 & $0.83 *$ \\
\hline & Exponential & 10.35 & 10.31 & 14.30 & 13.21 & 12.13* & 0.84 \\
\hline & Gaussian & 10.37 & 10.48 & $14.23 *$ & 13.04 & 11.97 & 0.84 \\
\hline \multirow{3}{*}{$\begin{array}{l}\text { Universal } \\
\text { Kriging }\end{array}$} & Spherical & 11.04 & 10.32 & 14.74 & 13.13 & 12.49 & 0.87 \\
\hline & Exponential & 11.00 & 10.36 & 14.83 & 13.19 & 12.60 & 0.85 \\
\hline & Gaussian & 10.99 & 10.29 & 14.65 & 13.11 & 12.56 & 0.85 \\
\hline
\end{tabular}


Tablo 3. Toprak parametrelerine uygulanan jeoistatistiksel yöntemler

\begin{tabular}{|c|c|c|c|c|c|}
\hline \multirow{2}{*}{ Enterpolasyon Models } & \multirow{2}{*}{ Power Semivariogram } & \multicolumn{4}{|c|}{ RMSE } \\
\hline & & Erozyon & Taşl111k & Derinlik & Otlatma \\
\hline \multirow{3}{*}{ İDW } & 1 & 1.31 & 1.07 & 0.76 & 0.74 \\
\hline & 2 & 1.34 & 1.10 & 0.85 & 0.77 \\
\hline & 3 & 1.41 & 1.16 & 0.93 & 0.82 \\
\hline \multirow{5}{*}{ RBF } & Completely Regularized Spline & 1.33 & 1.10 & 0.80 & 0.76 \\
\hline & Spline With Tension & 1.32 & 1.09 & 0.79 & 0.75 \\
\hline & Multiquadric & 1.46 & 1.25 & 0.92 & 0.86 \\
\hline & İnverse Multiquadric & 1.34 & 1.07 & 0.73 & 0.74 \\
\hline & Thin Plate Spline & 1.84 & 1.53 & 1.11 & 1.06 \\
\hline \multirow{3}{*}{ Ordinary Kriging } & Spherical & 1.29 & 1.11 & 0.72 & 0.75 \\
\hline & Exponential & 1.31 & 1.10 & 0.72 & 0.75 \\
\hline & Gaussian & 1.28 & 1.11 & 0.72 & 0.74 \\
\hline \multirow{3}{*}{ Simple Kriging } & Spherical & 1.28 & 1.01* & $0.69 *$ & 0.73 \\
\hline & Exponential & 1.31 & 1.02 & 0.69 & 0.73 \\
\hline & Gaussian & 1.28 & 1.01 & 0.69 & 0.73* \\
\hline \multirow{3}{*}{ Universal Kriging } & Spherical & 1.29 & 1.11 & 0.72 & 0.74 \\
\hline & Exponential & 1.31 & 1.10 & 0.72 & 0.75 \\
\hline & Gaussian & $1.28 *$ & 1.11 & 0.72 & 0.74 \\
\hline
\end{tabular}

\section{Bulgular}

Gümüşhane il merkezi dâhil 5 ilçeye (Kelkit, Köse, Kürtün, Şiran ve Torul) ait tüm mera ve yaylara ait detaylı bilgiler Tablo 4'te verilmiştir.

Tablo 4. Gümüşhane ili yaylalarının meralarına ait vejetasyon özellikleri

\begin{tabular}{|c|c|c|c|c|c|c|c|c|c|c|}
\hline İLÇESİ & KÖYÜ & BKA & BKÇ & BKİ & TKO & BKBa & BKBu & BKD & MSS & MDS \\
\hline Kelkit & Aydoğdu & 20.28 & 27.61 & 52.11 & 88.75 & 21.41 & 46.76 & 31.83 & Sağlıklı & Orta \\
\hline Kelkit & Babakonağ1 & 24.26 & 15.90 & 59.84 & 92.75 & 7.31 & 37.08 & 55.61 & Sağlıklı & Orta \\
\hline Kelkit & Balkaya & 16.90 & 10.80 & 72.30 & 53.25 & 21.13 & 25.35 & 53.52 & Sorunlu & Orta \\
\hline Kelkit & Cemalli & 25.71 & 11.43 & 62.86 & 52.50 & 10.48 & 33.33 & 56.19 & Sorunlu & Orta \\
\hline Kelkit & Çamur & 29.95 & 7.37 & 62.67 & 54.25 & 15.56 & 27.56 & 56.89 & Sorunlu & Orta \\
\hline Kelkit & Deliler & 24.55 & 17.69 & 57.76 & 69.25 & 4.33 & 38.63 & 57.04 & Riskli & Orta \\
\hline Kelkit & Deredolu & 31.54 & 28.52 & 39.93 & 74.50 & 4.28 & 51.68 & 44.04 & Sağliklı & İyi \\
\hline Kelkit & Devekorusu & 43.87 & 20.80 & 35.33 & 87.75 & 41.13 & 40.00 & 18.87 & Sağlıklı & $\begin{array}{l}\text { İyi } \\
\end{array}$ \\
\hline Kelkit & Doğankavak & 32.12 & 10.91 & 56.97 & 82.50 & 38.79 & 21.21 & 40.00 & Sağlıklı & Orta \\
\hline Kelkit & Gerdekhisar & 56.58 & 2.63 & 40.79 & 76.00 & 22.04 & 48.68 & 29.28 & Sağlıklı & İyi \\
\hline Kelkit & Gürleyik & 20.18 & 15.70 & 64.13 & 55.75 & 19.28 & 36.77 & 43.95 & Riskli & Orta \\
\hline Kelkit & Karacaören & 38.74 & 13.61 & 47.64 & 47.75 & 36.92 & 32.31 & 30.77 & Sorunlu & İyi \\
\hline Kelkit & Karşıyaka & 25.52 & 5.17 & 69.31 & 72.50 & 15.79 & 21.64 & 62.57 & Sağllklı & Orta \\
\hline Kelkit & Kılıçlı & 9.04 & 5.08 & 85.88 & 44.25 & 4.42 & 13.81 & 81.77 & Sorunlu & Zayıf \\
\hline Kelkit & Söğütlü bld, & 33.24 & 21.97 & 44.79 & 88.75 & 11.27 & 47.89 & 40.85 & Sağliklı & İyi \\
\hline Kelkit & Şen & 17.12 & 13.70 & 69.18 & 73.00 & 8.56 & 23.97 & 67.47 & Sağlıklı & Orta \\
\hline Kelkit & Tütenli & 14.77 & 7.69 & 77.54 & 81.25 & 6.46 & 32.92 & 60.62 & Sağlıklı & Zayıf \\
\hline Kelkit & Yeniköy & 25.77 & 16.84 & 57.39 & 72.75 & 8.93 & 35.74 & 55.33 & Sağliklı & Orta \\
\hline Köse & Kayadibi & 5.99 & 13.48 & 80.52 & 66.75 & 31.84 & 13.48 & 54.68 & Riskli & Zayıf \\
\hline Köse & Salyazı bld, & 34.27 & 15.73 & 50.00 & 71.50 & 11.72 & 42.07 & 46.21 & Sağliklı & Orta \\
\hline Köse & Yaylım & 22.22 & 15.63 & 62.15 & 72.00 & 26.74 & 39.58 & 33.68 & Sağlıklı & Orta \\
\hline Köse & Yuvacik & 10.18 & 6.91 & 82.91 & 68.75 & 21.82 & 17.09 & 61.09 & Riskli & Zayıf \\
\hline Kürtün & Arpacık & 23.89 & 14.44 & 61.67 & 45.00 & 3.86 & 49.76 & 46.38 & Sorunlu & Orta \\
\hline Kürtün & Elçiğen & 25.24 & 14.70 & 60.06 & 78.25 & 30.99 & 29.07 & 39.94 & Sağlıklı & Orta \\
\hline Kürtün & Günyüzü & 26.58 & 27.57 & 45.85 & 75.25 & 58.14 & 21.59 & 20.27 & Sağlıklı & Orta \\
\hline
\end{tabular}


Tablo 4. devam1

\begin{tabular}{|c|c|c|c|c|c|c|c|c|c|c|}
\hline İLÇESİ & KÖYÜ & BKA & BKÇ & BKİ & TKO & BKBa & BKBu & BKD & MSS & MDS \\
\hline Kürtün & Söğüteli & 32.63 & 0.00 & 67.37 & 59.00 & 34.32 & 22.46 & 43.22 & Riskli & Orta \\
\hline Kürtün & Tilkicek & 32.63 & 0.00 & 67.37 & 59.00 & 34.32 & 22.46 & 43.22 & Riskli & Orta \\
\hline Kürtün & Beşirköy & 17.20 & 14.52 & 68.28 & 46.50 & 17.74 & 32.26 & 50.00 & Sorunlu & Orta \\
\hline Kürtün & Göndere & 15.06 & 26.64 & 58.30 & 64.75 & 9.27 & 34.75 & 55.98 & Riskli & Orta \\
\hline Kürtün & Söğüteli & 21.86 & 34.13 & 44.01 & 83.50 & 34.13 & 39.52 & 26.35 & Sağlıklı & Orta \\
\hline Kürtün & Damlı & 34.90 & 34.56 & 30.54 & 74.50 & 34.82 & 48.56 & 16.61 & Sağlıklı & İyi \\
\hline Merkez & Arslanca & 33.88 & 4.61 & 61.51 & 76.00 & 29.28 & 37.17 & 33.55 & Sağlıklı & Orta \\
\hline Merkez & Beyçam & 20.59 & 20.59 & 58.82 & 68.00 & 10.29 & 41.18 & 48.53 & Riskli & Orta \\
\hline Merkez & Boğalı & 11.50 & 16.50 & 72.00 & 50.00 & 50.50 & 33.50 & 16.00 & Sorunlu & Orta \\
\hline Merkez & Çayırardı & 13.36 & 25.63 & 61.01 & 69.25 & 12.64 & 23.47 & 63.90 & Riskli & Orta \\
\hline Merkez & Çorak & 11.50 & 16.50 & 72.00 & 50.00 & 50.50 & 33.50 & 16.00 & $\begin{array}{l}\text { Sorunlu } \\
\end{array}$ & Orta \\
\hline Merkez & Güngören & 38.01 & 33.33 & 28.65 & 85.50 & 20.86 & 48.29 & 30.86 & Sağglıklı & İyi \\
\hline Merkez & Harmancık & 31.46 & 15.73 & 52.81 & 44.50 & 24.72 & 40.45 & 34.83 & Sorunlu & Orta \\
\hline Merkez & Kabaköy & 0.00 & 14.05 & 85.95 & 30.25 & 38.84 & 10.74 & 50.41 & Sorunlu & Zaylf \\
\hline Merkez & Kocapınar & 32.93 & 22.16 & 44.91 & 83.50 & 10.78 & 55.69 & 33.53 & Sağlıklı & İyi \\
\hline Merkez & Olucak & 16.30 & 20.65 & 63.04 & 46.00 & 27.17 & 9.24 & 63.59 & Sorunlu & Orta \\
\hline Merkez & Olucak 2 & 0.00 & 0.00 & 100.00 & 52.75 & 58.29 & 8.06 & 33.65 & Sorunlu & Zaylf \\
\hline Merkez & Yağlıdere & 41.67 & 16.67 & 41.67 & 72.00 & 12.14 & 41.53 & 46.33 & Sağlıklı & İyi \\
\hline Merkez & Yağmurdere & 26.42 & 10.94 & 62.64 & 66.25 & 25.37 & 32.46 & 42.16 & Riskli & Orta \\
\hline Merkez & Yaydemir & 42.68 & 19.82 & 37.50 & 82.00 & 47.46 & 14.03 & 38.51 & Sağlıklı & İyi \\
\hline Merkez & Yukarı alıçlı & 30.99 & 6.61 & 62.40 & 60.50 & 49.17 & 21.90 & 28.93 & Riskli & Orta \\
\hline Merkez & Yuvalı & 9.89 & 10.60 & 79.51 & 70.75 & 61.84 & 13.78 & 24.38 & Sağlıklı & Zayıf \\
\hline Merkez & Dumanl & 20.90 & 27.99 & 51.12 & 67.00 & 48.13 & 16.04 & 35.82 & Riskli & Orta \\
\hline Şiran & Alıç & 26.00 & 18.50 & 55.50 & 50.00 & 19.00 & 54.50 & 26.50 & Sorunlu & Orta \\
\hline Şiran & Arıtaş & 16.58 & 17.62 & 65.80 & 48.25 & 21.24 & 34.20 & 44.56 & Sorunlu & Orta \\
\hline Şiran & Çakırkaya & 31.29 & 23.62 & 45.09 & 81.50 & 15.34 & 54.60 & 30.06 & Sağlıklı & İyi \\
\hline Şiran & Çal & 20.74 & 11.48 & 67.78 & 67.50 & 14.44 & 42.59 & 42.96 & Riskli & Orta \\
\hline Şiran & Çevre pınarı & 3.80 & 35.44 & 60.76 & 79.00 & 12.03 & 28.48 & 59.49 & Sağlıklı & Zayif \\
\hline Şiran & Karaşeyh & 27.44 & 13.72 & 58.84 & 82.00 & 18.60 & 28.66 & 52.74 & Sağliklı & Orta \\
\hline Şiran & Kırıntı & 23.47 & 11.73 & 64.80 & 49.00 & 18.37 & 33.16 & 48.47 & Sorunlu & Orta \\
\hline Şiran & Kozağaç & 10.34 & 10.34 & 79.31 & 58.00 & 12.07 & 38.36 & 49.57 & Riskli & Zayif \\
\hline Şiran & Yedibölük & 12.66 & 50.21 & 37.13 & 59.25 & 25.74 & 40.08 & 34.18 & Riskli & Orta \\
\hline Torul & Ar1li & 15.02 & 10.58 & 74.40 & 73.25 & 30.41 & 8.11 & 61.49 & Sağlıklı & Zaylf \\
\hline Torul & Büyükçit & 23.11 & 16.73 & 60.16 & 62.75 & 35.86 & 6.37 & 57.77 & Riskli & Orta \\
\hline Torul & Dağdibi & 15.46 & 35.33 & 49.21 & 79.25 & 14.68 & 55.35 & 29.97 & Sağlıklı & Orta \\
\hline Torul & Gümüştuğ & 33.75 & 24.15 & 42.11 & 80.75 & 35.60 & 17.34 & 47.06 & Sağglıklı & İyi \\
\hline Torul & Güzeloluk & 20.53 & 20.53 & 58.94 & 75.50 & 11.00 & 38.51 & 50.49 & Sağglıklı & Orta \\
\hline Torul & Zigana & 22.50 & 19.06 & 58.44 & 80.00 & 36.25 & 26.88 & 36.88 & Sağlıklı & Orta \\
\hline
\end{tabular}

BKA: Azalııı bitkilerin kompozisyon oranı, BKÇ: Çoğalıcı bitkilerin kompozisyon oranı, BKİ: İstilacı bitkilerin kompozisyon oranı, TKO: Toprağı kaplama oranı, BKBa: Baklagiller familyasına ait bitkilerin kompozisyon oranı, BKBu: Buğdaygiller familyasına ait bitkilerin kompozisyon oranı, BKD: Diğer familyalara ait bitkilerin kompozisyon oranı, MSS: Mera sağlık sınıfı, MDS: Mera durum sınıfina ait

Gümüşhane mera ve yaylalarında toprağın ortalama bitkiyle kapl111k oranı \%67.18, bu oran içinde baklagillerin ortalama oranı \%24.55, buğdaygillerin oranı \%46.76 ve diğer familyaların oranı da \%43.45 olarak hesaplanmıştır. Türlerin kalite derecesine göre ise azalıcı bitki türlerinin oranı \%23.43, çoğalıcı bitki türlerinin oranı $\% 17.03$ ve istilacı türlerin oranı da $\% 59.51$ olarak belirlenmiştir (Şekil 2). 


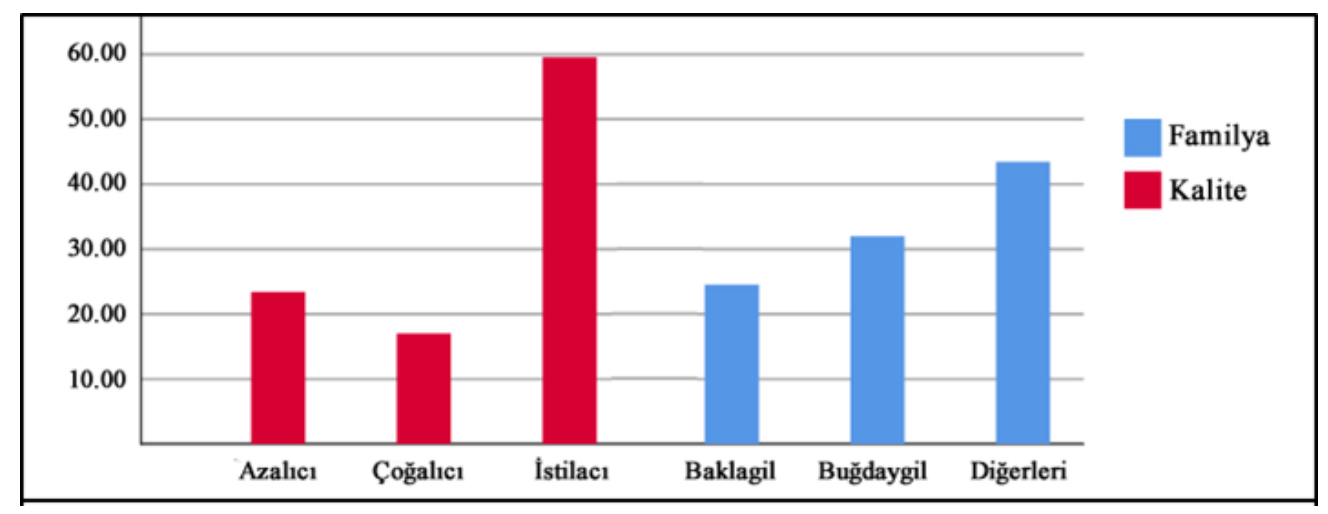

Şekil 2. Familya ve kalitelerine göre bitki türlerinin yoğunlukları

Özellikle mera ve yaylaların vejetasyonlarındaki istilac1 türlerin yoğun olduğu alanlar dikkate alındığında bu alanların mera sağlık sınıflarının riskli ve sorunlu, mera durum sınıflarının ise zayıf ve orta olduğunu söyleyebiliriz. Alanların durum sınıflarına genel olarak baktığımızda ise mera sağlık sınıfi bakımından, alanların \%49.21'i sağlıklı iken sorunlu ve riskli alanların oranının
\%25.40 olduğu hesaplanmıştır. Mera durum sinıfina göre ise alanların \%65.08'i orta, $\% 19.05$ 'i iyi ve \%15.87'si zayıf mera durum sinıfina sahip olduğu bulunmuştur (Şekil 3). Mera durum sınıfi ile mera sağlık sınıfının iyi olmadığ 1 alanlarda azalıcı türlerin vejetasyondaki oranlarının arttırılması ve istilacı türlerle mücadele yöntemlerinin uygulanması gereklidir.

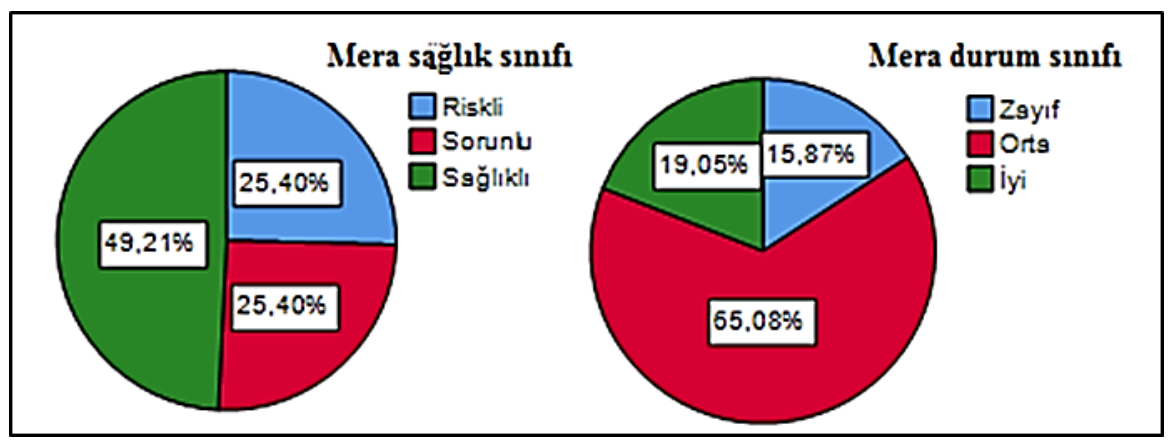

Şekil 3. Mera ve yaylaların sağlık ve durum sınıfları

Meraların vejetasyon özelliklerine ait çizilen haritalar incelendiğinde; baklagiller familyasına ait türlerin en yoğun olduğu (\%51-61) yerlerin Trabzon il sınırına yakın olan yaylalar olduğu jeoistatistik analiziyle belirlenmiştir. Bunu yanı sıra bu yerlere yakın olan yaylalar ile Giresun il sınırına yakın olan Torul ilçesindeki alanlarda baklagiller familyasına ait türlerin oranlarının \%50'ye yakın olduğu belirlenmiştir. Özellikle Şiran ilçesinde yer alan mera ve yaylalardaki baklagiller familyasına ait türlerin yoğunluğunun \%3-15 arasında değiştiği bulunmuştur (Şekil 4a).

Buğdaygiller familyasına ait türlerin dağılımına baktığımızda Bayburt ilinin kuzey ve batı sınırına yakın yerler, Giresun ilinin Alucra ve Çamoluk ilçelerine yakın sınırlar ile Erzincan ili sınırına yakın yerlerde buğdaygiller familyasına ait türlerinin yoğunluğunun $\% 46-55$ arasında değiştiği görülmektedir. Buğdaygiller familyası türlerine ait yoğunluğun az olduğu mera ve yaylalar ise Gümüşhane ilinin orta kesimlerindedir. Sonuç olarak; baklagiller familyasına ait tür yoğunluğunun kuzeyden güneye doğru azaldığı, buğdaygiller familyasına ait türlerin yoğunluğunu ise Gümüşhane merkezine doğru azaldığını söyleyebiliriz (Şekil $4 b)$. 


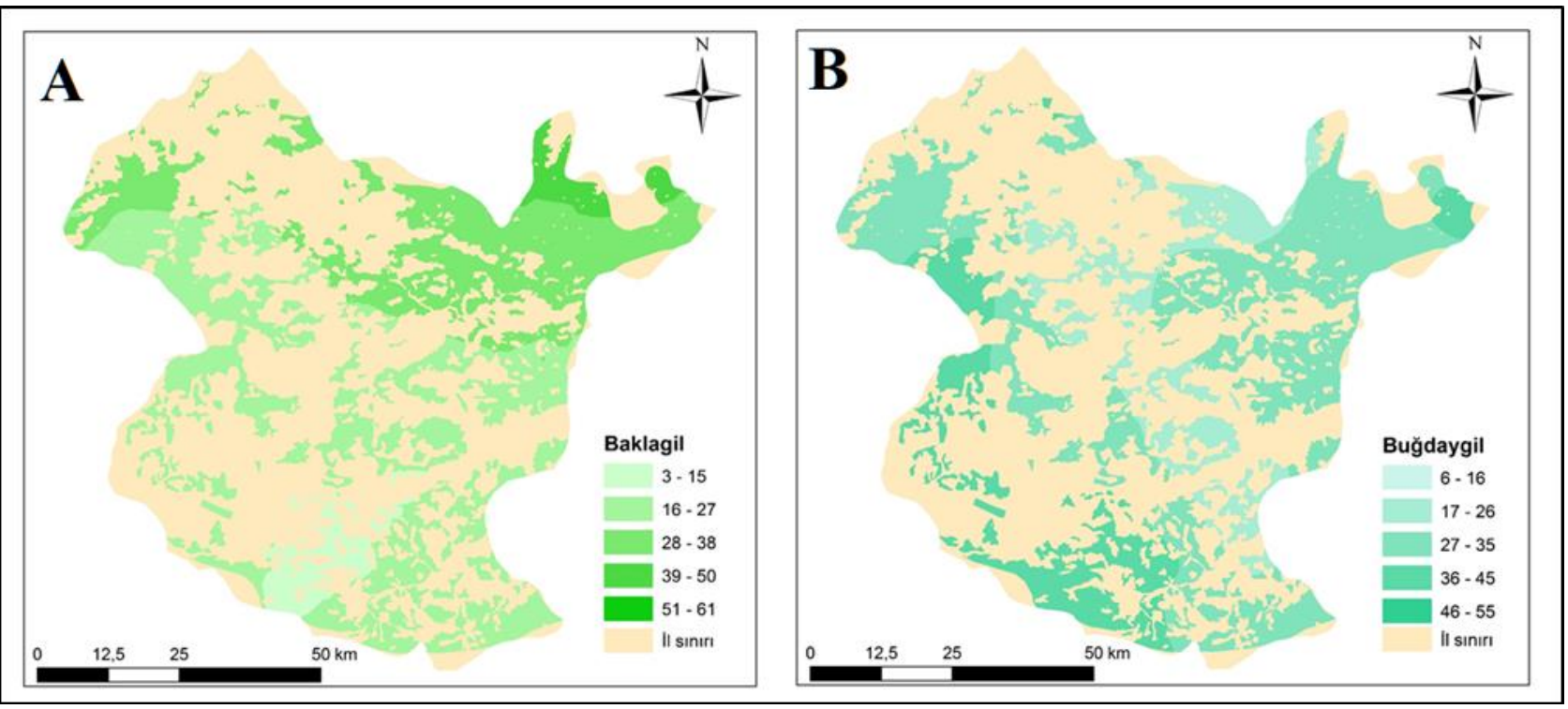

Şekil 4. Mera ve yaylalara ait baklagiller (a) ve buğdaygillere (b) ait türlerin yoğunluk haritaları
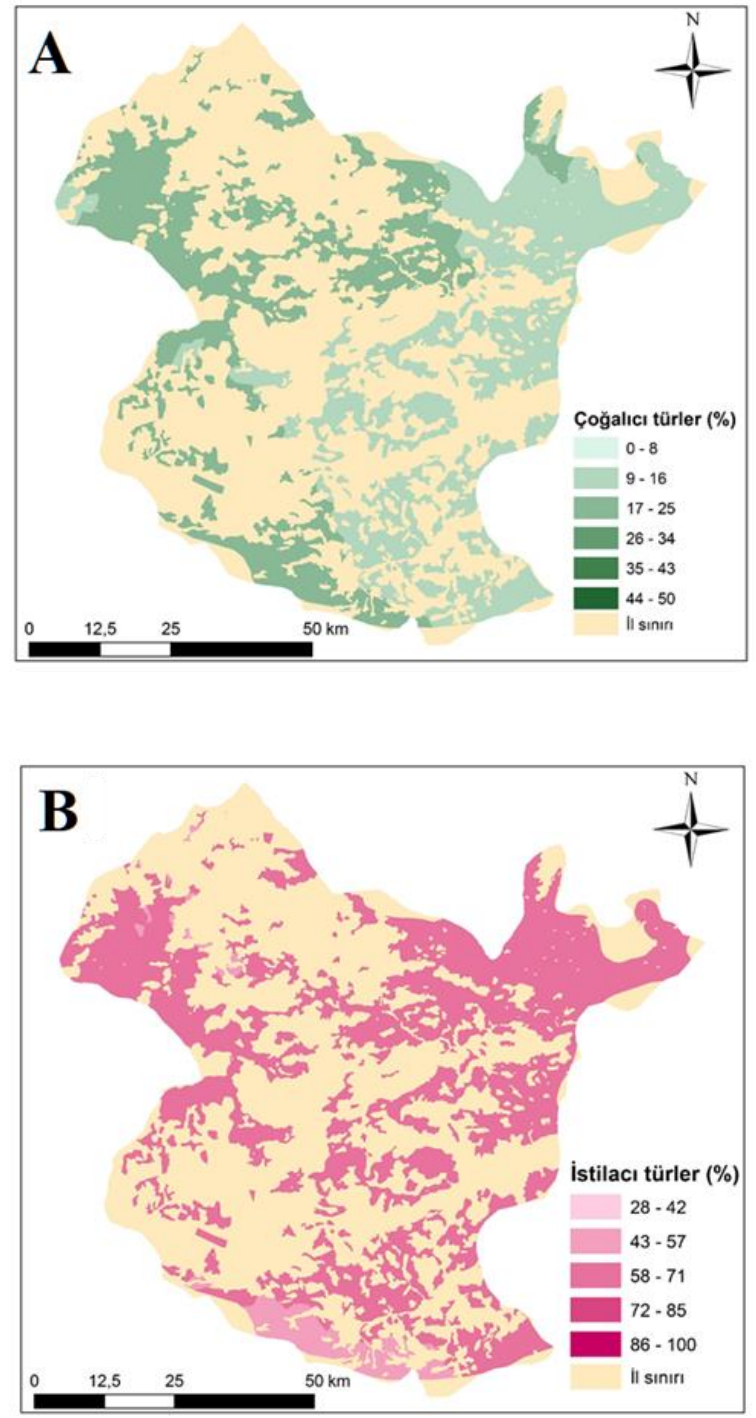

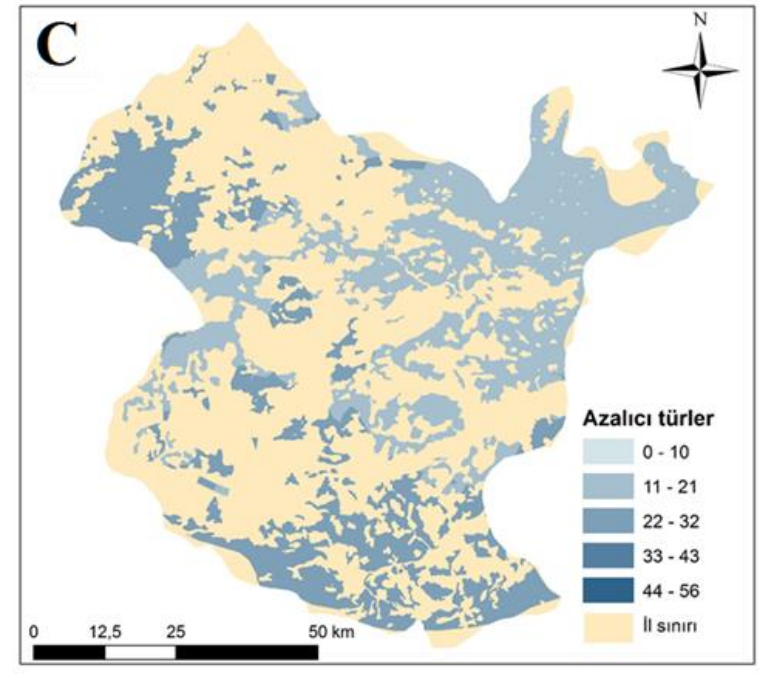

Şekil 5. Mera ve yaylalara ait çoğalıcı (a), istilacı (b) ve azalıcı (c) türlerin yoğunluk haritaları

Türlerin kalite derecelerine göre çizilen haritalar incelendiğinde; çoğalıcı türlerin yoğunluğunun bazı mera ve yaylalarda \%50'ye çıktığ1 görülmektedir. Genel olarak Gümüşhane ilinin doğusunda kalan mera ve yaylalarda çoğalıcı türlerin yoğunluğunun batıdaki mera ve yaylalara göre daha az olduğu söylenebilir. Özellikle Bayburt il sınırına yakın yerlerde çoğalıcı tür yoğunluğunun $\% 5$ civarında olduğu görülmektedir (Şekil 5a).

Son olarak istilacı türlerin yoğunluğunu gösteren harita incelendiğinde; genel olarak Gümüşhane ilindeki mera ve yaylalarda yoğun olduğu görülmektedir. İstilacı tür yoğunluğunun az 
olduğu yerler ise Erzincan il sınırlarına yakın olan yayla ve meralardır. Yoğun olduğu yayla ve meralar özellikle çoğalıcı ve azalıcı tür yoğunluğunun az olduğu Trabzon ve Bayburt il sınırına yakın olan yerlerdir (Şekil 5b).

Azalıcı tür yoğunluğunun gösterildiği harita incelendiğinde ise; Gümüşhane ilinin Erzincan ili sınırlarına ve Giresun ili Alucra ve Çamoluk ilçelerine yakın yayla ve meralarda \%33-56 arasında değiştiği görülmektedir. Azalıcı tür yoğunluğunun az olduğu yayla ve meralar ise daha çok Trabzon ve Bayburt il sınırına yakın yerler ile Gümüşhane merkezinde yer alan yayla ve meralardır (Şekil 5c).

Meralarının sağlı durumu haritası incelendiğinde; genel olarak mera ve yaylaların sağlıklı olduğu görülmektedir. Bununla birlikte sorunlu alanlarda bulunmaktadır. Mera durum sınıflarına baktığımızda meraların genel durumunun iyi ve orta dereceli olduğu görülmektedir. 10 farklı mera alanında ise mera durumunun zayıf olduğu görülmüştür (Şekil 6).

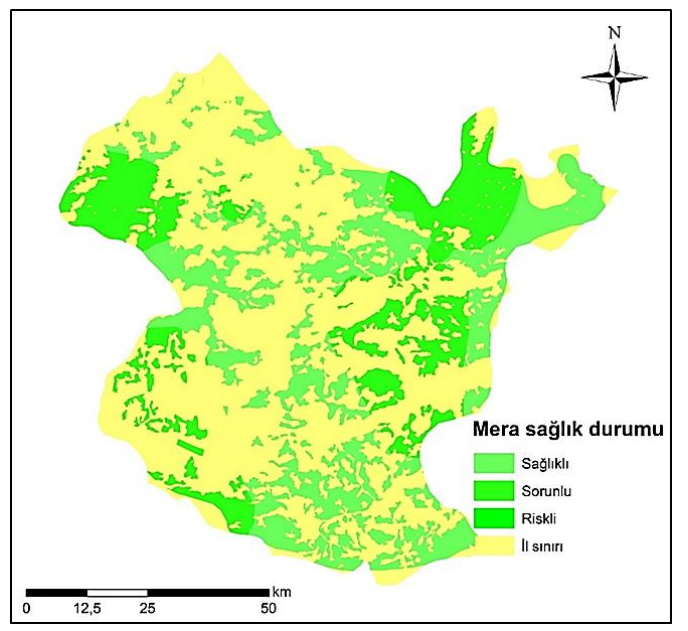

Şekil 6. Mera ve yaylaların mera sağlık durumu haritas 1

Coğrafi konumundaki farklılardan dolay1 Gümüşhane ili mera ve yaylaları eğim, erozyon derecesi, taşlılık ve toprak derinliği bakımından oldukça farklılık gösterir. Ayrıca otlatma şiddeti de çalışılan her bir mera alanı içinde ayrı ayrı belirlenmiştir (Tablo 5).

Tablo 5. Gümüşhane ili yaylalarının meralarına ait çevresel özellikler

\begin{tabular}{|c|c|c|c|c|c|c|}
\hline İlçesi & Köyü & Otlatma & Ĕğim & Erozyon derecesi & Taşlılık & Derinlik \\
\hline Kelkit & Aydoğdu & 2- Hafif & 4- Dik Eğimli & 2- Hafif & $2-\mathrm{Az}$ & 1- Çok Sı̆̆ \\
\hline Kelkit & Babakonağ1 & 2- Hafif & 4- Dik Eğimli & 3- Orta & 4- Çok & $2-\mathrm{S} 1 \breve{\mathrm{g}}$ \\
\hline Kelkit & Balkaya & 4- Yoğun & 5- Çok Dik Eğimli & 6- Çok Şiddetli & 4- Çok & 1- Çok Sı̆̆ \\
\hline Kelkit & Cemalli & 4- Yoğun & 3- Orta Eğimli & 5- Şiddetli & 4- Çok & 1- Çok Sı̆ \\
\hline Kelkit & Çamur & 2- Hafif & 6- Arızalı & 3- Orta & 4- Çok & 1- Çok Sı̆ \\
\hline Kelkit & Deliler & 3- Orta & 6- Arızalı & 4- Yüksek & 5- Aşır1 & 1- Çok Sı̆̆ \\
\hline Kelkit & Deredolu & 3- Orta & 3- Orta Eğimli & 2- Hafif & $2-\mathrm{Az}$ & 3- Orta Derin \\
\hline Kelkit & Devekorusu & 2- Hafif & 4- Dik Eğimli & 2- Hafif & $2-\mathrm{Az}$ & 2- Sı \\
\hline Kelkit & Doğankavak & 2- Hafif & 5- Çok Dik Eğimli & 3- Orta & $2-\mathrm{Az}$ & 1- Çok Sı̆ \\
\hline Kelkit & Gerdekhisar & 3- Orta & 1- Hemen Hemen Düz & 1- Çok Hafif & 1- Çok Az & 4- Derin \\
\hline Kelkit & Gürleyik & 3- Orta & 3- Orta Eğimli & 4- Yüksek & 4- Çok & 1- Çok Sı̆ \\
\hline Kelkit & Karacaören & 3- Orta & 3- Orta Eğimli & 4- Yüksek & 4- Çok & 1- Çok Sı ̌̆ \\
\hline Kelkit & Karşıyaka & 2- Hafif & 3- Orta Eğimli & 2- Hafif & $2-\mathrm{Az}$ & 1- Çok Sı̆ g \\
\hline Kelkit & Kılıçlı & 3- Orta & 5- Çok Dik Eğimli & 4- Yüksek & 4- Çok & 2- Sığ \\
\hline Kelkit & Söğütlü bld. & 2- Hafif & 2- Hafif Eğimli & 2- Hafif & 1- Çok Az & 3- Orta Derin \\
\hline Kelkit & Şen & 3- Orta & 4- Dik Eğimli & 3- Orta & $2-\mathrm{Az}$ & 2- Sı̆ \\
\hline Kelkit & Tütenli & 3- Orta & 4- Dik Eğimli & 4- Yüksek & 4- Çok & 1- Çok Sı̆ \\
\hline Kelkit & Yeniköy & 4- Yoğun & 3- Orta Eğimli & 6- Çok Şiddetli & 4- Çok & 1- Çok Sı̆̆ \\
\hline Köse & Kayadibi & 3- Orta & 4- Dik Eğimli & 4- Yüksek & 3- Orta & 1- Çok Sı ̆ \\
\hline Köse & Salyazı bld. & 2- Hafif & 3- Orta Eğimli & 3- Orta & $2-\mathrm{Az}$ & 2- S1 \\
\hline Köse & Yaylım & 4- Yoğun & 5- Çok Dik Eğimli & 5- Şiddetli & 3- Orta & 1- Çok Sı̆̆ \\
\hline Kürtün & Arpacık & 2- Hafif & 3- Orta Eğimli & 3- Orta & 3- Orta & 2- Si $\breve{g}$ \\
\hline Köse & Yuvacık & 4- Yoğun & 3- Orta Eğimli & 4- Yüksek & 3- Orta & 1- Çok Sı ̆̆ \\
\hline Kürtün & Elçiğen & 3- Orta & 1- Hemen Hemen Düz & 2- Hafif & $2-\mathrm{Az}$ & 2- S1 $\breve{g}$ \\
\hline Kürtün & Günyüzü & 3- Orta & 5- Çok Dik Eğimli & 2- Hafif & $2-\mathrm{Az}$ & 1- Çok Sı̆ \\
\hline Kürtün & Söğüteli & 3- Orta & 6- Arrzal1 & 3- Orta & 3- Orta & 1- Çok Sı̆̆ \\
\hline
\end{tabular}


Tablo 5. devam1

\begin{tabular}{|c|c|c|c|c|c|c|}
\hline İlçesi & Köyü & Otlatma & Ĕ̆im & Erozyon derecesi & Taşlılık & Derinlik \\
\hline Kürtün & Tilkicek & 3- Orta & 6- Arızalı & 3- Orta & 3- Orta & 1- Çok Sı̆̆ \\
\hline Kürtün & Beşirköy & 2- Hafif & 5- Çok Dik Eğimli & 4- Yüksek & 4- Çok & 2- Siğ \\
\hline Kürtün & Göndere & 2- Hafif & 5- Çok Dik Eğimli & 3- Orta & 3- Orta & 2- S1 ̆ \\
\hline Kürtün & Söğüteli & 2- Hafif & 3- Orta Eğimli & 2- Hafif & 3- Orta & 1- Çok Sı̆̆ \\
\hline Kürtün & Damlı & 2- Hafif & 4- Dik Eğimli & 2- Hafif & 3- Orta & 2- S1 $\breve{g}$ \\
\hline Merkez & Arslanca & 3- Orta & 3- Orta Eğimli & 2- Hafif & 1- Çok Az & 3- Orta Derin \\
\hline Merkez & Beyçam & 4- Yoğun & 4- Dik Eğimli & 4- Yüksek & 3- Orta & 1- Çok Sı̆̆ \\
\hline Merkez & Boğalı & 3- Orta & 2- Hafif Eğimli & 2- Hafif & 1- Çok Az & 2- Siğ \\
\hline Merkez & Çayırardı & 3- Orta & 5- Çok Dik Eğimli & 5- Şiddetli & 3- Orta & 1- Çok Sı ̆ \\
\hline Merkez & Çorak & 3- Orta & 3- Orta Eğimli & 2- Hafif & $2-\mathrm{Az}$ & 3- Orta Derin \\
\hline Merkez & Güngören & 2- Hafif & 5- Çok Dik Eğimli & 2- Hafif & $2-\mathrm{Az}$ & 1- Çok Sı̆̆ \\
\hline Merkez & Harmancık & 3- Orta & 5- Çok Dik Eğimli & 5- Şiddetli & 4- Çok & 1- Çok Sı̆̆ \\
\hline Merkez & Kabaköy & 2- Hafif & 5- Çok Dik Eğimli & 6- Çok Şiddetli & 4- Çok & 2- Siğ \\
\hline Merkez & Kocapınar & 2- Hafif & 4- Dik Eğimli & 3- Orta & 4- Çok & 1- Çok Sı̆ \\
\hline Merkez & Olucak & 2- Hafif & 3- Orta Eğimli & 3- Orta & 4- Çok & 1- Çok Sı̆̆ \\
\hline Merkez & Olucak 2 & 4- Yoğun & 4- Dik Eğimli & 2- Hafif & 3- Orta & 2- S1 $\breve{g}$ \\
\hline Merkez & Yağlıdere & 3- Orta & 4- Dik Eğimli & 2- Hafif & 3- Orta & 3- Orta Derin \\
\hline Merkez & Yağmurdere & 2- Hafif & 5- Çok Dik Eğimli & 3- Orta & 4- Çok & 1- Çok Sığ \\
\hline Merkez & Yaydemir & 3- Orta & 2- Hafif Eğimli & 2- Hafif & 3- Orta & 2- Si $\breve{g}$ \\
\hline Merkez & Yukarı alıçlı & 4- Yoğun & 6- Arızalı & 6- Çok Şiddetli & 5- Aşırı & 1- Çok Sı̆̆ \\
\hline Merkez & Yuvalı & 3- Orta & 3- Orta Eğimli & 2- Hafif & 3- Orta & 1- Çok Sı ̆̆ \\
\hline Merkez & Dumanlı & 2- Hafif & 4- Dik Eğimli & 3- Orta & 3- Orta & 1- Çok Sı ̆̆ \\
\hline Şiran & Alıç & 4- Yoğun & 2- Hafif Eğimli & 6- Çok Şiddetli & 3- Orta & 1- Çok Sı̆̆ \\
\hline Şiran & Arıtaş & 4- Yoğun & 3- Orta Eğimli & 4- Yüksek & 4- Çok & 1- Çok Sı̆̆ \\
\hline Şiran & Çakırkaya & 2- Hafif & 1- Hemen Hemen Düz & 1- Çok Hafif & 1- Çok Az & 2- Si $\breve{g}$ \\
\hline Şiran & Çal & 4- Yoğun & 5- Çok Dik Eğimli & 6- Çok Şiddetli & 4- Çok & 1- Çok Sı̆̆ \\
\hline Şiran & Çevre pınarı & 3- Orta & 4- Dik Eğimli & 4- Yüksek & 3- Orta & 1- Çok Sı̆̆ \\
\hline Şiran & Karaşeyh & 3- Orta & 2- Hafif Eğimli & 1- Çok Hafif & 3- Orta & 2- Si $\breve{g}$ \\
\hline Şiran & Kırınt1 & 4- Yoğun & 5- Çok Dik Eğimli & 6- Çok Şiddetli & 4- Çok & 1- Çok Sı̆̆ \\
\hline Şiran & Kozağaç & 3- Orta & 5- Çok Dik Eğimli & 4- Yüksek & 3- Orta & 1- Çok Sı̆̆ \\
\hline Şiran & Yedibölük & 3- Orta & 5- Çok Dik Eğimli & 4- Yüksek & 4- Çok & 1- Çok Sĭg \\
\hline Torul & Ar1li & 2- Hafif & 5- Çok Dik Eğimli & 3- Orta & 3- Orta & 1- Çok Sı̆̆ \\
\hline Torul & Büyükçit & 2- Hafif & 4- Dik Eğimli & 3- Orta & 3- Orta & 1- Çok Sı̆̆ \\
\hline Torul & Dağdibi & 2- Hafif & 5- Çok Dik Eğimli & 3- Orta & 4- Çok & 1- Çok Sı̆̆ \\
\hline Torul & Gümüştuğ & 3- Orta & 4- Dik Eğimli & 2- Hafif & $2-\mathrm{Az}$ & 2- S1 $\breve{g}$ \\
\hline Torul & Güzeloluk & 2- Hafif & 1- Hemen Hemen Düz & 2- Hafif & $2-\mathrm{Az}$ & 2- S1 $\breve{g}$ \\
\hline Torul & Zigana & 2- Hafif & 5- Çok Dik Eğimli & 2- Hafif & 1- Çok Az & 2- Sı $\breve{g}$ \\
\hline
\end{tabular}

Mera ve yaylaların otlatma şiddeti ve eğim dereceleri incelendiğinde; otlatma şiddetinin yoğun olduğu mera oranının $\% 19.05$ olduğu, hafif olduğu mera oranı ise \%39.68 olarak bulunmuştur. Eğim derecesine baktığımızda ise çok değişken olduğu görülmektedir. 6 farklı eğim sınıfına sahip olan çalışma alanlarının \%30.16's1 çok dik eğime sahiptir. Hemen hemen düz ve hafif eğime sahip alanların oranı ise \%14.30 olarak bulunmuştur (Şekil 7). 


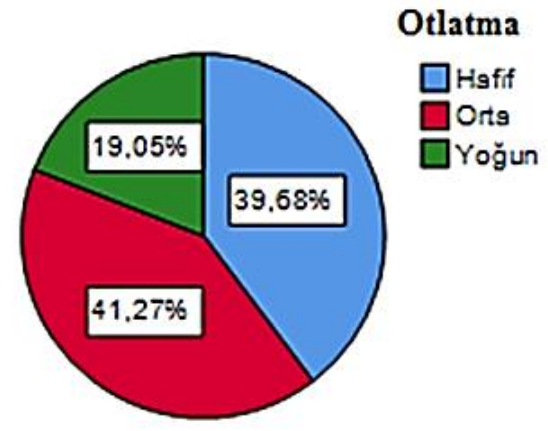

Eğim

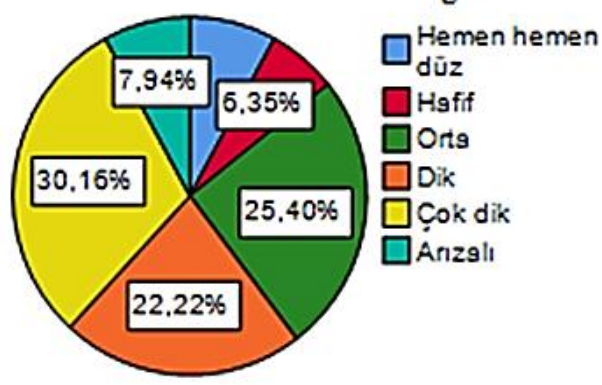

Şekil 7. Mera ve yaylalara ait otlatma ve eğim sınıflarının dağılımı

Erozyon, taşl1lık ve derinlik sınıflandırmalarına göre alanlar incelendiğinde her bir özelliğin çok değişken olduğu söylenebilir. Erozyon derecelerine göre alanların \%30.16'sinda hafif derecede erozyon görülürken, \%11.1'inde çok şiddetli erozyon görülmektedir. Taşl11ık yönünden aşırı ve çok taşlı olan alanların oranı $\% 34.94$, çok ve az taşlı olan alanların oranı ise \%30.20 olarak bulunmuştur (Şekil 8).

Çalışma alanının özellikle eğim değerlerinin yüksek oluşu sahip olduğu akarsu sayısının çok olması arazinin fazla sayıda parçalanmasına neden olmaktadır. Bu parçalanmalardan dolayı çalışılan mera ve yaylalar farklı bakılara sahiptir. Güneyde bulunan sahalar eğimi düşük yüksek plato özelliği göstermesine karşın, vadi tabanlarının ise düz ve düze yakın eğime sahip bir özellik sergilemektedir. Düz alanların büyük bir kısmı yine güneyde bulunan Kelkit ve Şiran ovalarından oluşmaktadır (Şekil 9a).

İl envanterlerinde yer alan arazi bilgilerine göre çizilen eğim ve arazi kullanım haritaları incelendiğinde; mera alanlarının yaygın olduğu, sonrasında ise orman alanlarının ilde hâkim olduğu görülmektedir (Şekil 9b). Yer yer fundalık alanları bulunmaktadır. Ormanlık alanlar il arazilerinin yaklaşık \%25 ini kaplamaktadır. Tarım alanları yaklaşık 1130 kilometrekarelik bir alanda görülmektedir.
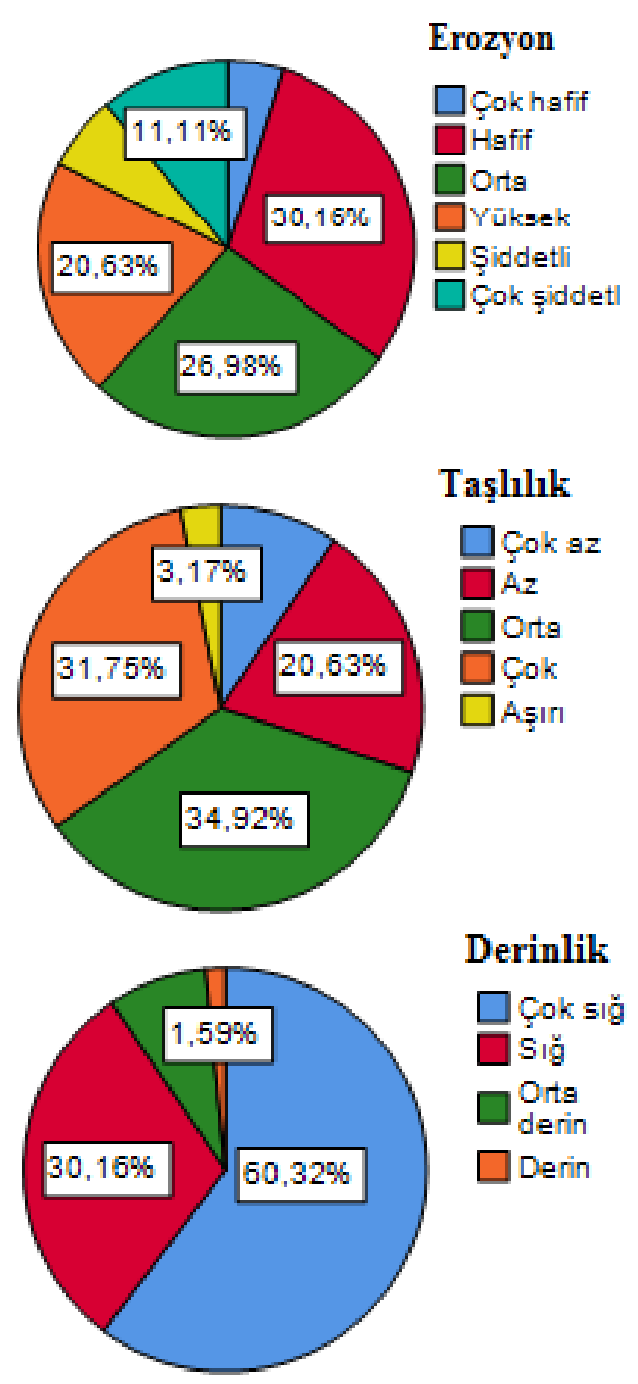

Şekil 8. Mera ve yaylalara ait erozyon, taşlık ve toprak derinliği sınıflarının dağılımı

Fakat nadasa birakılan ve birakılmayan kuru tarım alanlar1 yaygındır. Plato seviyelerinde kuru tarım alanlarının daha yaygın olduğu, güneye doğru vadi tabanlarında ise sulu tarım yapıldığ görülmektedir. Mera alanlarının Trabzon güneyinde kalan kesimlerde ve Bayburt sınırına doğru daha yaygın olduğu görülmektedir. İlin arazilerinin yaklaşık \%35'lik bir kısmında bulunan mera alanları yaklaşı 2800 kilometrekaredir.

Mera arazilerinin toprak derinlik durumu incelendiğinde toprak derinliğinin oldukça düşük olduğu görülmektedir (Şekil 10a). Meralarının erozyon değerlendirme haritasina göre ilde, hafif ve orta şiddetli erozyon görülen sahaların yaygın olduğu görülmektedir. Orta şiddetli erozyon sahaları Harşit çayı ve büyük kollarının yayılış gösterdiği alanda görülmektedir. 


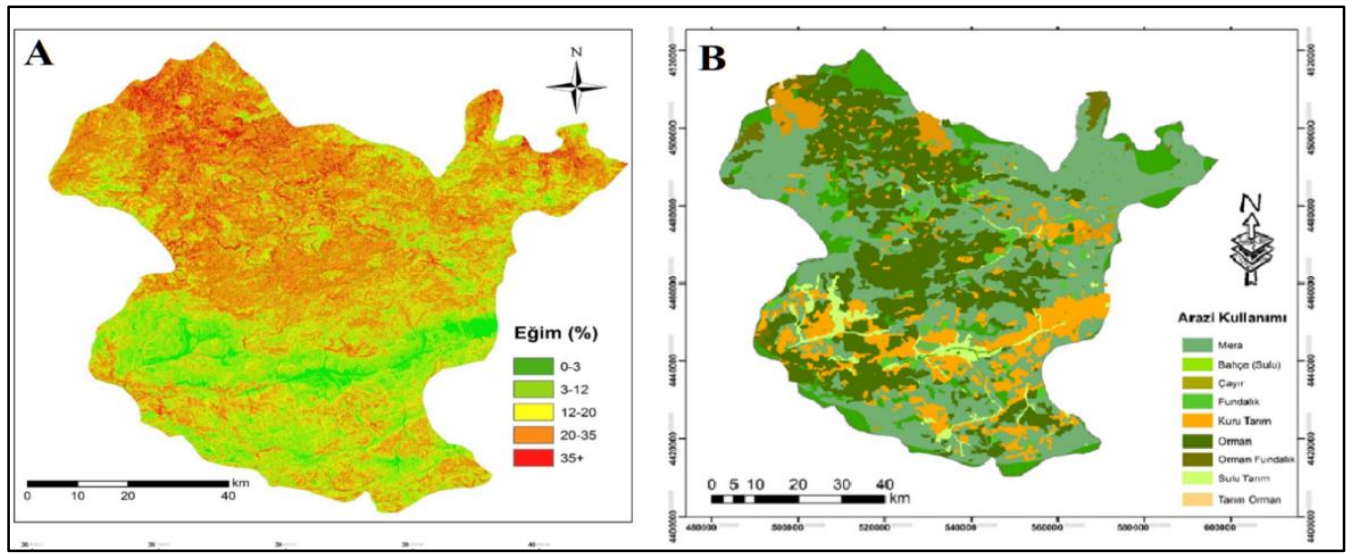

Şekil 9. Mera ve yaylalara ait eğim haritası (a) ve Gümüşhane ili arazi kullanım haritası (b)

İlin batısında küçük bir alanda ise yüksek erozyon olduğu görülmektedir. Erozyon miktarının düşük olması ve kayalık alanların bol olmasıyla beklenenden düşük olması toprak derinliklerinin ilişkili olduğu düşünülmektedir (Şekil 10b).

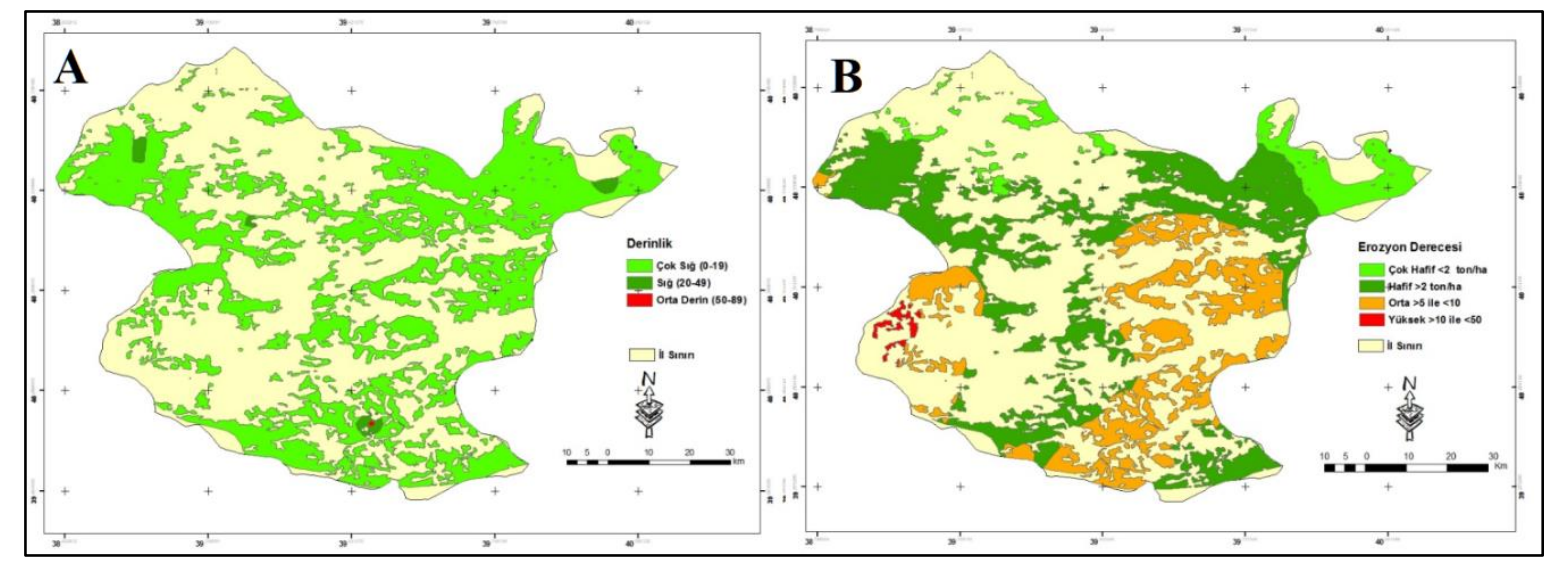

Şekil 10. Mera ve yaylalara ait toprak derinliği (a) ve erozyon derecesi (b) haritaları

Otlatma durumu incelendiğinde, orta dereceli otlatma alanlarının ağırlıkta olduğu görülmektedir. Yoğun otlatmanın görüldüğü 12 adet mera alanı belirlenmiştir. İlin kuzeybatısında ve güneydoğusunda küçük alanlarda ise otlatmanın hafif dereceli olduğu görülmüştür. İlin kuzeybatısında ve güneydoğusunda küçük alanlarda ise otlatmanın hafif dereceli olduğu görülmüştür (Şekil 11a). Taşl11ık toprak özellikleri, jeolojik formasyon özellikleri ve erozyon gibi çeşitli sebeplere bağlı olarak değişkenlik gösteren bir durumdur. Meralarda taşlilık probleminin çok fazla olmadığı görülmektedir. Az derecede taşl1lık hâkim görülürken birkaç mera arazisinde orta derecede taşl1lık görülmektedir (Şekil 11b).
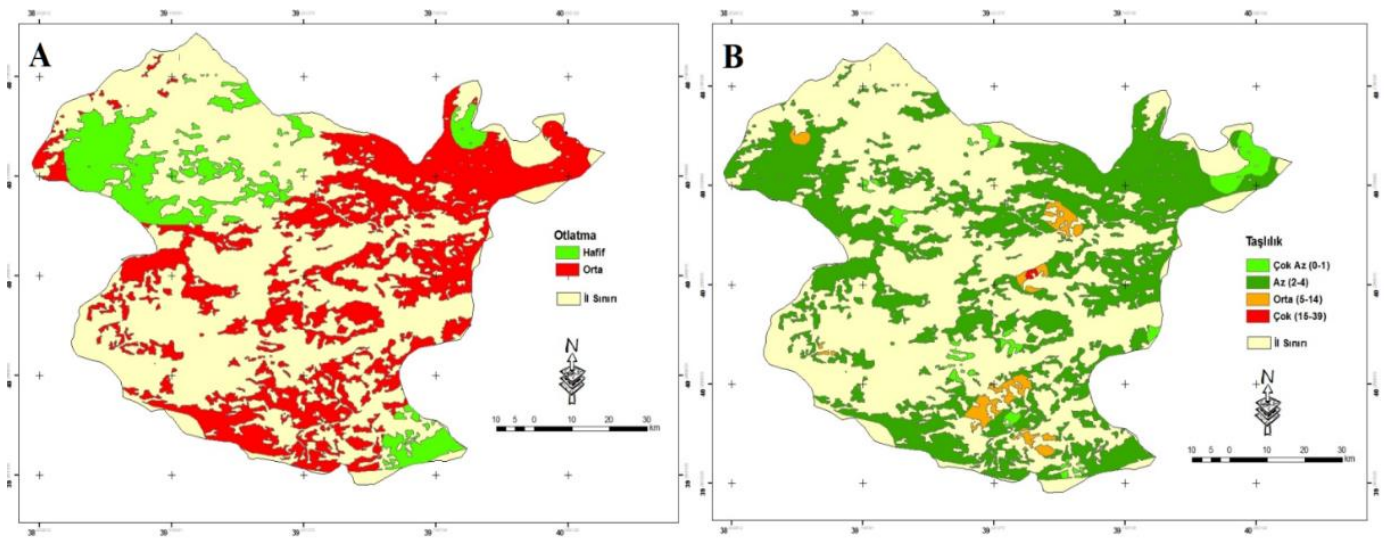

Şekil 11. Mera ve yaylalara ait otlatma şiddeti (a) ve taşl11ık (b) haritaları 


\section{Tartışma}

Meralarda uygulanacak her türlü amenajman çalışmalarının başarılı olabilmesi için, meraların botanik kompozisyonu hakkında yeterli bilgiye sahip olunmas1 gereklidir (İspirli vd., 2016). Bunun yanında meralara ait çevresel özelliklerin belirlenmesi de yapılacak çalışmalara katkı sağlaması açısından önemlidir. $\mathrm{Bu}$ çalışmada; Gümüşhane ili mera ve yaylaların hem vejetasyon hem de çevresel özelliklerine ait bilgiler ortaya konmuştur. Bunun yanında bu özelliklere ait alansal dağılım haritalarının çizilmesi, Gümüşhane ilindeki tüm mera ve yaylalara ait vejetasyon ve çevresel özellikler hakkında bilgiler elde edilmiştir.

Meraları oluşturan türlerin kompozisyonu bölgeden bölgeye farkl1l1klar göstermekle birlikte özellikle buğdaygiller familyasına ait türlerin her yerde yüksek orana sahip olduğu belirtilmiştir (Koç vd. 2005). Bulgular Gümüşhane mera ve yaylalarının botanik kompozisyonlarının sonuç değerleri ile uygunluk göstermektedir. Ayrıca bu çalışmadaki meraların çoğunda buğdaygiller familyasına ait türlerin yüksek olduğu, baklagiller familyasına ait türlerin yoğunluğunun ise daha az olduğu ancak yoğun olduğu yerlerde de \%61'e kadar yükseldiği belirlenmiştir.

Türlerin kalite derecelerine göre ise istilac1 türlerin yoğunluğunun çoğalıcı ve azalıcı türlere göre çok yükssek olduğu belirlenmiştir. Fakat bu yüksek oran Trabzon ve Bayburt sinırlarına yakın yerlerde yoğunlaştığı için Gümüşhane ili genelinde bu durum söz konusu değildir. Mera sağlığı, meralarda farklı çevresel faktörler altında devamlılığın sağlanmasını (Altın vd., 2011), mera durumu ise floristik kompozisyona göre vejetasyonun mevcut durumu ifade eder (Bakır, 1999). Bu çalışmada genel olarak mera ve yaylaların sağlıklı olduğu görülmektedir. Mera durum sinıflarına göre ise meraların genel durumunun iyi ve orta derecede olduğu belirlenmiştir. Araştırma sonuçlarına göre, ülkemiz meralarının ortalamasına yakın bir oran göstermiştir (Töngel ve Ayan, 2005; Yavuz vd., 2012; Seydoşoğlu vd., 2018). Mera durumunun riskli sınıfına girdiği alanlarda bitki türlerinin zayıf olduğu görülmüş, arazi çalışmaları sırasında erozyonun nispeten fazla olduğu meralarda kapalılığın da az olduğu gözlemlenmiştir.

Besin değeri yüksek bitkilerin meralardan aşırı otlatma nedeniyle uzaklaştığ 1 ve bu türlerin yerine yem değeri düşük bitkilerin yerleştiği bilinmektedir (Türk vd., 2015). Bu çalışmada orta dereceli otlatma alanlarının ağırlıkta olduğu, aşırı otlamanın ise merkez ve Şiran ilçelerinde yer alan bazı meralarda tespit edilmiştir. Aşırı otlatmanın görüldüğü alanlarda özellikle diğer familyalara ait türlerin yoğun olarak görüldüğü tespit edilmiştir. Buna karşın yıllar içerisinde hayvancılıkta bir değişimin yaşanması meralarda aşırı otlatma problemini ortadan kaldırmıştır (Sürmen ve Kara, 2018). Meralarda otlatma süreci başlangıç tarihi belirlenirken dikkatli olunmalıdır. Ayrıca açı meralarda salma hayvanc1lık yapma yerine artık kapalı ya da yarı kapalı ahırlarda besi hayvancılığ 1 tercih edilmektedir (Alkan ve Ersin, 2018). Bitkilerin bahar döneminde henüz otlatma olgunluğuna gelmeden otlatılması bitki gelişimini engellemekte ve yeterli ot bulamayan hayvanların bitkileri tamamen yok etmesine sebep olabilmektedir. Bu da zamanla meralar üzerindeki hayvan baskısının azalmasına sebep olmuştur. Amiri vd. (2008), otlatma miktarının toprağın fiziksel özelliklerini olumsuz etkilediğini belirtirken; Curtis ve Wright (1993) ile Sun ve Liddle (1993) otlatma derecesinin, mera ve mera toprağı üzerinde değişikliklere neden olduğu ortaya konmuştur. Yine başka bir çalışmada otlatmanın mera topraklarının sıkışmasını kolaylaştırdığını ortaya koymuştur (Bari vd., 1993).

Artan eğim ile birlikte meralarda otlatma şiddeti azalmakta erozyonun neden olduğu toprak kaybı ile verimde de azalmalar ortaya çıkmaktadır. $\mathrm{Bu}$ durum, Altın vd. (2011)'ne göre eğim arttıkça yüzey akışının arttığını bundan dolayı da taban meranın eğimli meraya göre daha verimli olduğunu; Koç vd. (2005)'ne göre de taban suyu seviyelerinin mera kesimleri arasındaki verim farklılıklarına neden olduğu yaptıkları çalışmalarda belirtmişlerdir. İlin arazi yapısında gözlemlenen formasyonların cinsi ve özellikleri toprak gelişimine uygun olmadığı, oluşan az toprağın ise yüksek eğim değerlerine, erozyona bağlı aşınma ve taşınmaya neden olduğu belirlenmiştir (Altın vd., 2005). Ülkemizdeki meraların çoğunluğunun eğimli ve arızalı arazilerde olduğu dikkate alındığında (Büyükburç, 1999), özellikle eğim artışı ile birlikte yaş ot veriminin düştüğü Sürmen ve Kara (2018) tarafindan yapılan çalışmada ortaya konmuştur. Yapılan çalışmalar farklı eğimlere sahip meraların ot verimlerinin farklı olduğunu ortaya koymaktadır (Şen vd., 2017).

Bunların yanında otlatmanın, erozyon riskinin daha az olduğu mera alanlarında daha basit ve uygulanabilir olması ile yararlı bitkiler üzerindeki olumsuz etkilerinin daha az olması açısından daha 
tercih edilebilir olduğu kabul edilmektedir (Gökbulak, 1997). Bu sahalarda erozyon probleminin önüne geçilmesi, mevcut bitki yoğunluğunun arttırılması gerekmektedir. İspirli vd. (2016) tarafindan Kastamonu Taşköprü sınırlarında kalan bazı meralarda yaptıkları çalışmalarda, örtünün yoğun olmasına rağmen yıllar içinde erozyona bağlı toprakların taşındığı ve derinliğin sığ olduğu görülmüş ve Karadeniz Bölgesi meraları için bitki kapalılı̆̆ının yüksek olmasının hayati önemi olduğu vurgulanmıştır. Örnek parsellere bakıldığında düşük erozyon miktarının olduğu parsellerde toprak derinliğinin sığ ya da çok sığ olduğu görülmektedir.

Taşl111k; toprak özellikleri, jeolojik formasyon özellikleri ve erozyon gibi çeşitli sebeplere bağl1 olarak değişkenlik gösteren bir durumdur. Meralarda taşlılık probleminin çok fazla olmadığ görülmektedir. Az derecede taşl11ık, hâkim görülürken birkaç mera arazisinde orta derecede taşlilık görülmektedir. Taşlılık probleminin yüksek olması mera arazilerindeki bitki ile kapll1ık, ot verimi ve mera sağlık durumunun düşmesine sebep olmaktadır (Ünal vd., 2012). Çok sığ $(0-19 \mathrm{~cm})$ derinlik seviyesinde olan mera arazileri otsu bitkilerin yetişmesine yetecek seviyede olmakla birlikte fazla gelişmelerine de imkân tanımamaktadır (İspirli vd., 2016). Mera arazilerinin toprak derinlik durumu incelendiğinde toprak derinliğinin oldukça düşük olduğu görülmektedir.

Sonuç olarak Gümüşhane ili yayla ve meralarının genel olarak sağl1klı olduğu, sorunlu ve riskli olan meraların ise aşırı otlatılan ve toprak derinliğinin daha düşük meralar olduğu tespit edilmiştir. Ayrıca bu çalışmada jeoistatistik yöntemler ile mera ve yaylalara ait vejetasyon ve çevresel özelliklerin haritaları çizilmiştir. Günümüzde meralara ait vejetasyon ve çevresel özelliklerin haritalanması özellikle mera amenajman ve ıslah çalışmalarının başarısını arttırmaktadır. Böylece meraların doğal yapısına kavuşması sağlanmaktadır.

\section{Teșekkür}

$\mathrm{Bu}$ çalışma Türkiye Bilimsel ve Teknolojik Araştırma Kurumu (TÜBİTAK) tarafından 106G017 numaralı proje ile desteklenmiştir.

\section{Kaynaklar}

Aksakal, E.L. ve Öztaş, T., 2010. Changes in Distribution Patterns of Soil Penetration Resistance Within a Silage-Corn Field
Following The Use Of Heavy Harvesting Equipments. Turkish Journal of Agriculture and Forestry, 34(2), 173-179.

Alkan, H. ve Ersin, M.Ö., 2018. Korunan Doğal Alanlarda İnsan-Yaban Hayatı Çatışması. Türkiye Ormancılık Dergisi, 19(3), 284-292.

Altın, M., Gökkuş, A. ve Koç, A., 2011. Çayır ve Mera Yönetimi. T.C. Tarım ve Köyişleri Bakanlığı Tarımsal Üretim ve Geliştirme Genel Müdürlüğü Yayınları, Ankara, 186s.

Altın, M., Tuna, C., Nizam, İ. ve Ateş, E., 2005. Pirinççi Köyü Meraları Dolgu Alanlarını Bitkilendirme Uygulamaları, VI. Tarla Bitkileri Kongresi, Eylül 2005, Antalya, Türkiye, s.11571162.

Amiri, F., Ariapour, A. ve Fadai, S., 2008. Effects of Livestock Grazing on Vegetation Composition and Soil Moisture Properties in Grazed and Non-Grazed Range Site. Journal of Biological Sciences, 8(8), 1289-1297.

Anonim, 2005. Toprak ve Arazi Sinıflaması Standartları Teknik Talimat1, http://www. tarim.gov.tr/Belgeler /Mevzuat/ Talimatlar/ Toprak Arazi Siniflamasi Standartlari Teknik TalimativeIlgiliMevzuat_yeni.pdf.

Arslan, H., 2012. Spatial and Temporal Mapping of Groundwater Salinity Using Ordinary Kriging and Indicator Kriging: The Case of Bafra Plain, Turkey. Agricultural Water Manangement, 113, 57-63.

Ayan, İ., Mut, H., Acar, Z., Başaran, U., Töngel, M.Ö. ve Önal Aşçı, Ö., 2007. Samsun İli Kıyı Kesiminde Yer Alan Taban Meraların Bitki Örtüsü, Toprak Özellikleri ve Bazı Sorunlar, Türkiye VII. Tarla Bitkileri Kongresi, Haziran 2007, Erzurum, Türkiye, s.54-57.

Bakır, Ö., 1999. Otlatma Kapasitesi. Mera Kanunu Eğitim ve Uygulama El Kitabı. T.C. Tarım ve Köy İşleri Bakanlı̆̆ı, Tarımsal Üretim ve Geliştirme Genel Müdürlüğü Yayınları, Ankara, $314 s$.

Bari, F., Wood, M.K. ve Murray, L., 1993. Livestock Grazing Impacts on Infiltration Rates in a Temperate Range of Pakistan. Journal of Range Management, 46(4), 367-372.

Blanchet, K., Moechnig, H. ve DeJong-Hughes, J., 2003. Grazing Systems Planning Guide. University of Minnesota Extension Service, BU-07606-S, http://www.extension.umn.edu/ agriculture/ beef/ components/ docs/ grazingsystemsplanning.guide.pdf. 
Büyükburç, U., 1983. Ankara İli Yavrucak Köyü Meralarının Gübreleme ve Dinlendirme Yolu ile Islahı Olanakları Üzerinde Bir Araştırma, Çayır Mera ve Zootekni Araştırma Enstitüsü Yayınları, 79, Ankara, 161s.

Büyükburç, U., 1999. Mera ve Çayırların Önemi ve Özellikleri. T.C. Tarım ve Köy İşleri Bakanlığı, Tarımsal Üretim ve Geliştirme Genel Müdürlügü, Çayır-Mera Yem Bitkileri ve Havza Geliştirme Daire Başkanlığı, Ankara.

Cevher, C., Altınkaynak, B., Ataseven, Y., Köksal, Ö., Yavuz, G.G., Gül, U. ve Ataseven Yasan, Z., 2015. Türkiye'de Islah Edilmiş Meraların Sürdürülebilirliği Üzerine Bir Araştırma: Edirne, Afyonkarahisar, Aksaray, Niğde ve Uşak, Ardahan, Artvin, Çorum, Erzurum ve Kars İlleri Örneği. Tarımsal Ekonomi ve Politika Geliştirme Enstitüsü Yayınları, 252, Ankara, 101s.

Curtis, D. ve Wright, T., 1993. Natural Regeneration and Grazing Management a Case Study. Australian Journal of Soil and Water Conservation, 6(4), 30-34.

Davis, P.H., 1965-1985. Flora of Turkey and the East Aegean Islands, Vol. 1-9: Edinburgh University Press, Edinburgh.

Davis, P.H., Mill, R.R. ve Tan, K., 1988. Flora of Turkey and the East Aegean Islands (supplement), Vol. 10: Edinburgh University Press, Edinburgh.

Gökbulak, F., 1997. Otlatmanın Otlak Ekosistemi İçin Önemi. İstanbul Üniversitesi Orman Fakültesi Dergisi, 47, 57-61.

Gökkuş, A., Koç, A. ve Çomaklı, B., 2000. Çayır-Mera Uygulama Kılavuzu. Atatürk Üniversitesi, Ziraat Fakültesi, Yayın No: 142, Erzurum.

Güner, A., Özhatay, N., Ekim, T. ve Başer, K.H.C., 2000. Flora of Turkey and the East Aegean Islands, Supplement, Vol. 11: Edinburgh University Press, Edinburgh.

İmamoğlu, A. ve Dengiz, O., 2017. Determination of Soil Erosion Risk Using RUSLE Model and Soil Organic Carbon Loss In Alaca Catchment (Central Black Sea region, Turkey). Rendiconti Lincei, 28(1), 11-23.

İmamoğlu, A. ve Dengiz, O., 2019. Evaluation of Soil Quality Index to Assess The Influence of Soil Degradation and Desertification Process In SubArid Terrestrial Ecosystem. Rendiconti Lincei. Scienze Fisiche e Naturali, 1-12.
İmamoğlu, A., Bahadır, M. ve Dengiz, O., 2016. Çorum Alaca Havzasında Toprak Erozyon Duyarlılık Faktörünün Farklı Enterpolasyon Modeller Kullanılarak Konumsal Dağılımlarının Belirlenmesi. Toprak Su Dergisi, 5(1), 8-15.

İspirli, K., Alay, F., Uzun, F. ve Çankaya, N., 2016. Doğal Meralardaki Vejetasyon Örtüsü ve Yapısı Üzerine Otlatma ve Topografyanın Etkisi. Türkiye Tarımsal Araştırmalar Dergisi, 3, 1422.

Karagüllü, O. ve Kendüzler, M., 2008. CORINE Siniflandirması Raporu. Orman Genel Müdürlügü, Orman Harita ve Fotogrametri Müdürlüğü, Ankara.

Koç, A. ve Çakal, Ş., 2004. Comparison of Some Rangeland Canopy Coverage Methods. International Soil Congress Natural Resource Management for Sustainable Development, June 2004, Erzurum, Türkiye, s.41-45.

Koç, A., Gökkuş, A. ve Altın, M., 2003. Mera Durumu Tespitinde Dünyada Yaygın Olarak Kullanılan Yöntemlerin Mukayesesi ve Türkiye İçin Bir Öneri, Türkiye V. Tarla Bitkileri Kongresi, Ekim 2003, Diyarbakır, Türkiye, s.36-42.

Koç, A., Sürmen, M. ve Kaçan, K., 2005. Erzincan Ovası Taban Meralarının Bitki Örtülerinin Mevcut Durumu. Türkiye VI. Tarla Bitkileri Kongresi Bildiri Kitabı, Eylül 2005, Antalya, Türkiye, Cilt II, s. 847-850.

McGrath, D., Zhang, C. ve Carton, O.T., 2004. Geostatistical Analyses and Hazard Assessment on Soil Lead in Silvermines Area. Ireland. Environmental Pollution, 127(2), 239-248.

Ongun, A.R., 2008. Toprakların Bazı Fiziksel ve Kimyasal Özelliklerinin Jeoistatistiksel Yöntemlerle Uzaysal Değişkenliğinin Saptanmas1. Doktora Tezi, Ege Üniversitesi. Fen Bilimleri Enstitüsü, İzmir, 139s.

Seydoşoğlu, S., Kökten, K. ve Sevilmiş, U., 2018. Basic Vegetation Characteristics of Village Pastures Connected to Mardin Province and Its Provinces. Turkish Journal of Agricultural and Natural Sciences, 5(4), 406-413.

Sun, D. ve Liddle, M.J., 1993. A Survey of Trampling Effects On Vegetation and Soil in Eight Tropical and Sub-Tropical Areas. Environmental Management, 17(4), 497-510.

Sürmen, M. ve Kara, E., 2018. Aydın İli Ekolojik Koşullarında Farklı Eğimlerdeki Mera Vejetasyonlarının Verim ve Kalite Özellikleri. Derim, 35(1), 67-72. 
Sürmen. M., Yavuz, T., Sürmen, B. ve Kutbay, H.G., 2015. Determination of the Population Densities of İnvasive Species in Meadows and Pastures of Samsun. Türkiye Herboloji Dergisi, 18(3), 9-10.

Şen, C., Günay, S., Kurt, C. ve Tuna, Y.T., 2017. Farklı Eğim Derecelerindeki Korunan ve Otlatılan Meralarda Bazı Islah Metotlarının Bitki Örtüsü Üzerine Etkileri. KSÜ Doğa Bilimleri Dergisi, 20, 52-59.

Şengönül, K., Kara, Ö., Palta, Ş. ve Şensoy, H., 2009. Bartın Uluyayla Yöresindeki Mera Vejetasyonunun Bazı Kantitatif Özelliklerinin Saptanması ve Ekolojik Yapının Belirlenmesi. Bartın Orman Fakültesi Dergisi, 11(16), 81-94.

Töngel, M.Ö. ve Ayan, İ., 2005. Samsun İli Çayır ve Meralarında Yetişen Bazı Zararlı Bitkiler ve Hayvanlar Üzerindeki Etkileri. OMÜ Ziraat Fakültesi Dergisi, 20(1), 84-93.

Turan, N., Özyazıcı, M.A. ve Tantekin, G.Y., 2015. Siirt İlinde Çayır Mera Alanlarından ve Yem Bitkilerinden Elde Edilen Kaba Yem Üretim Potansiyeli. Türkiye Tarımsal Araştırmalar Dergisi, 2(1), 69-75.

Turgut, B. ve Öztaş, T., 2012, Assessment of Spatial Distribution of Some Soil Properties with
Geostatistics Method. Süleyman Demirel Üniversitesi Ziraat Fakültesi Dergisi, 7(2),1022.

Türk, M., Albayrak, S. ve Bozkurt, Y., 2015. Otlatmanın Farklı Yapay Meralarda Botanik Kompozisyon Üzerine Etkisi. Süleyman Demirel Üniversitesi Ziraat Fakültesi Dergisi, 10(1), 27-34.

Ünal, S., Mutlu, Z., Mermer, A., Urla, Ö., Ünal, E., Özaydın, K.A., Avağ, A., Yıldız, H., Aydoğmuş, O., Şahin, B. ve Aslan, S., 2012. Çankırı İli Meralarının Mera Durumu ve Sağlığının Belirlenmesi Üzerine Bir Çalışma. Tarım Bilimleri Araştırma Dergisi, 5(2), 131135 .

Ünal, S., Mutlu, Z., Urla, Ö., Yıldız, H., Aydoğdu, M., Şahin, B. ve Aslan, S., 2014. Improvement Possibilities and Effects of Vegetation Subjected to Long-Term Heavy Grazing In The Steppe Rangelands Of Sivas. Tarla Bitkileri Merkez Araştırma Enstitüsü Dergisi, 23(1), 2230 .

Yavuz, T., Sürmen, M., Töngel, M.Ö., Avağ, A., Özaydın, K. ve Yıldız, H., 2012. Amasya Mera Vejetasyonlarının Bazı Özellikleri. Tarım Bilimleri Araştırma Dergisi, 5(1), 181-185. 